\title{
Evaluation of Nonpoint-Source Contamination, Wisconsin: Water Year 1999
}

By J.F. Walker, D.J. Graczyk, S.R. Corsi, J.A. Wierl, and D.W. Owens

U.S. GEOLOGICAL SURVEY

Open-File Report 01-105

In cooperation with the

Wisconsin Department of Natural Resources

Middleton, Wisconsin

2001

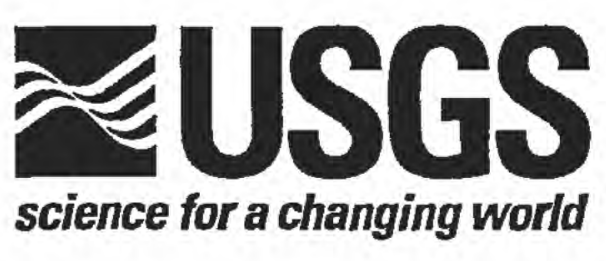




\title{
U.S. DEPARTMENT OF THE INTERIOR GALE A. NORTON, Secretary
}

\author{
U.S. GEOLOGICAL SURVEY \\ Charles G. Groat, Director
}

Any use of trade, product, or firm names is for descriptive purposes only and does not imply endorsement by the U.S. Government.

For additional information write to:

District Chief

U.S. Geological Survey

8505 Research Way

Middleton, WI 53562-3586
Copies of this report can be purchased from:

U.S. Geological Survey

Branch of Information Services

Box 25286

Denver, CO 80225-0286 


\section{CONTENTS}

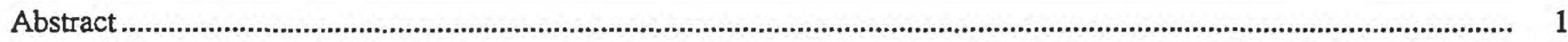

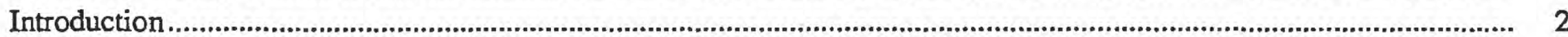

Land-use and best-management practice inventories ………………......................................................................... 3

Activities through 1999 water year....................................................................................................................... 3

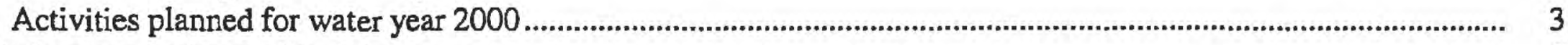

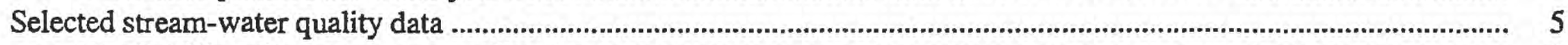

Availability of stream-water quality data............................................................................................................... 5

Summary of loads at rural stream sites ............................................................................................................ 5

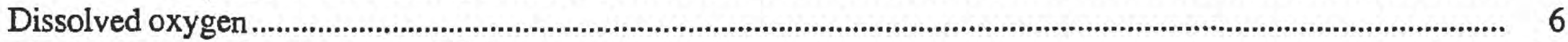

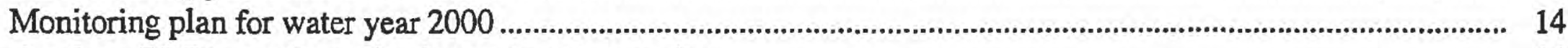

Analysis of pre-BMP constituent loads at urban stream sites........................................................................................ 14

Analysis of load trends at rural stream sites ........................................................................................................................... 17

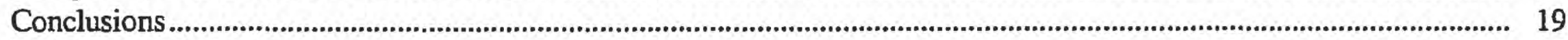

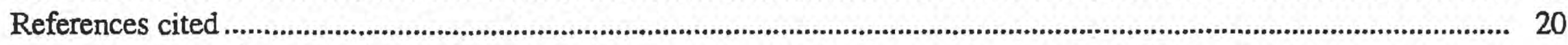

Appendix. Storm-load data for rural watershed-management evaluation monitoring sites, Wisconsin, water years $1985-98$

\section{FIGURES}

1. Map showing locations of rural and urban sites in the Wisconsin watershed-management evaluation monitoring program

2-4. Graphs showing:

2. Number of storms through water year 1998 for which loads were calculated at the evaluation-monitoring sites

3. Return period, in days, that the dissolved-oxygen concentration was less than a given concentration for one continuous hour, May through September, for water years 1990-96 at Garfoot Creek, Wisconsin

4. Return period, in days, that the dissolved-oxygen concentration was less than a given concentration for one continuous hour, May through September, for water years 1990-96 at Otter Creek, Wisconsin

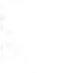

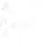

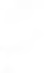
(1) 6

(1)

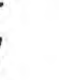
. 


\section{CONVERSION FACTORS AND ABBREVIATED WATER-QUALITY UNITS}

\begin{tabular}{rll}
\hline Multiply & By & To Obtain \\
inch (in.) & & millimeter \\
foot (ft) & 25.4 & meter \\
acre & 0.3048 & hectare \\
square mile $\left(\mathrm{mi}^{2}\right)$ & 0.4048 & square kilometer \\
million cubic feet $\left(\mathrm{Mft}^{3}\right)$ & 2.590 & million cubic meters \\
pound $(\mathrm{lb})$ & 0.02832 & gram \\
pounds per square mile $\left(\mathrm{lb} / \mathrm{mi}^{2}\right)$ & 453.6 & kilograms per square $\mathrm{kilometer}\left(\mathrm{kg} / \mathrm{km}{ }^{2}\right)$ \\
ton $(\mathrm{short})$ & 0.17573 & megagram $(\mathrm{Mg})$ \\
& 0.9072 & \\
Temperature in degrees Celsius $\left({ }^{\circ} \mathrm{C}\right)$ can be converted to degrees Fahrenheit $\left({ }^{\circ} \mathrm{F}\right)$ by use of the following equation: & \\
& ${ }^{\circ} \mathrm{F}=1.8\left({ }^{\circ} \mathrm{C}\right)+32$. & \\
\end{tabular}

Abbreviated water-quality units used in this report: Chemical concentrations and water temperature are given in metric units. Chemical concentration is given in milligrams per liter ( $\mathrm{mg} / \mathrm{L})$, micrograms per liter $(\mu \mathrm{g} / \mathrm{L})$. Milligrams per liter is a unit expressing the concentration of chemical constituents in solution as weight (milligrams) of solute per unit volume (liter) of water. One thousand micrograms per liter is equivalent to one milligram per liter. For concentrations less than $7,000 \mathrm{mg} / \mathrm{L}$, the numerical value is the same as for concentrations in parts per million. 


\title{
Evaluation of Nonpoint-Source Contamination, Wisconsin, Water Year 1999
}

\author{
By J.F. Walker, D.J. Graczyk, S.R. Corsi, J.A. Wierl, and D.W. Owens
}

\section{Abstract}

The objective of the watershed-management evaluation monitoring program in Wisconsin is to evaluate the effectiveness of best-management practices (BMPs) for controlling nonpoint-source pollution in rural and urban watersheds. This progress report provides a summary of the data collected by the U.S Geological Survey for the program and a discussion of the results from several different detailed analyses conducted within this program.

A land-use and best-management-practice inventory is ongoing for each evaluation monitoring project to track the different sources of nonpointsource pollution in each watershed and to document implementation of best-management programs that may cause changes in the water quality of streams. Updated information is gathered each year, mapped, and stored in a geographic-information-system database. Summaries of BMP-implementation data collected through the 1999 water year are presented in this report.

Suspended sediment and total phosphorus storm-load and annual-load data are summarized for eight rural sites. For all 8 rural sites a sufficient number of pre-BMP storm samples have been collected; for two of the sites (Brewery and Garfoot Creeks), a sufficient number of post-BMP storm samples have been collected to allow for a final assessment of the effectiveness of the BMPs. For the remaining sites, numerous transitional storm samples have been collected, but in all cases BMP implementation has lagged such that there are insufficient post-BMP storm samples for final analysis. For two sites (Rattlesnake and Kuenster Creeks) there are not enough planned BMPs to warrant further data collection.

Continuous dissolved-oxygen data collected at 5 rural sites are summarized. In terms of instanta- neous concentrations when comparing pre-BMP data to transitional and post-BMP data, the general trend is a reduction in the number of days that the dissolved oxygen concentration was less than the state standard. These results are anecdotal, however; the differences have not been rigorously tested statistically. For a level of dissolved oxygen sustained over a continuous hour, the results are mixed. In general the number of days with standard violations has decreased, but there are notable exceptions.

For the four urban streams, the pre-BMP data were examined to determine the level of improvement that could potentially be detected with a statistical analysis. Regression analyses were performed relating constituent loads of suspended solids, total phosphorus and total copper to various independent variables, including seasonal terms and variables related to rainfall. On the basis of the residuals from the regressions, there is a wide range of potential change that could be detected with an analysis of pre- and post-BMP loads. This is likely a result of the high degree of variability in the data, particularly from site to site. For suspended solids, total phosphorus, and total recoverable copper the minimum detectable changes ranges from $20-80,30-70$ and 30-90 percent, respectively.

For two of the eight rural streams (Rattlesnake and Kuenster Creeks) minimal BMP implementation has occurred, hence a comparison of preBMP and data collected after BMP implementation began is not warranted. For two other rural streams (Brewery and Garfoot Creeks), BMP implementation is complete. For the four remaining rural streams (Bower, Otter, Eagle, and Joos Valley Creeks), the pre-BMP load data were compared to the transitional data to determine if significant reductions in the loads have occurred as a result of the BMP implementation to date. For all sites, the actual constituent loads for suspended solids and 


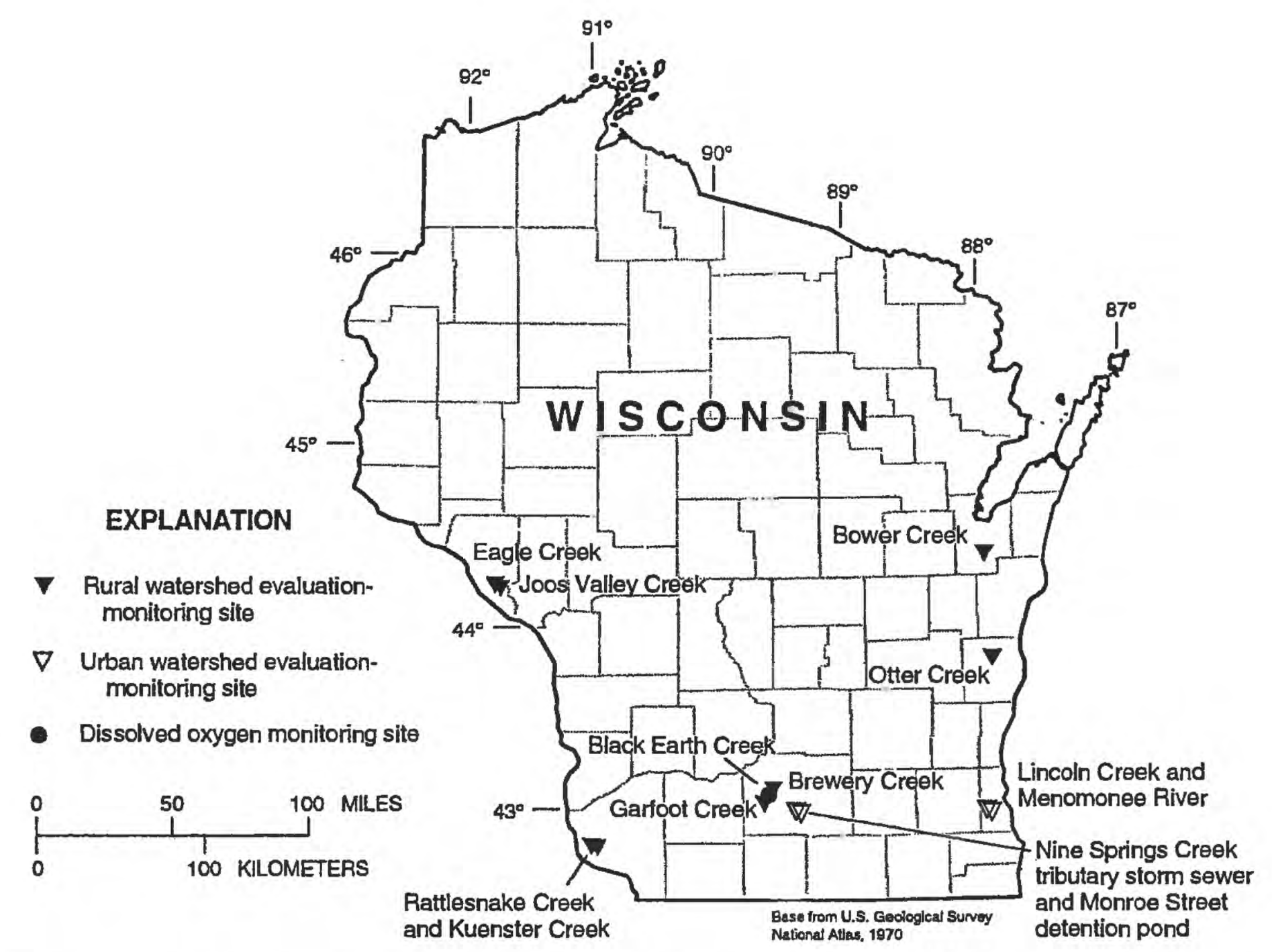

Figure 1. Locations of rural and urban sites in the Wisconsin watershed-management evaluation monitoring program.

total phosphorus exhibit no statistically significant reductions after BMP installation. Multiple regressions were used to remove some of the natural variability in the data. Based on the residual analysis, for Otter Creek, there is a significant difference in the suspended-solids regression residuals between the pre-BMP and transitional periods, indicating a potential reduction as a result of the BMP implementation after accounting for natural variability. For Joos Valley Creek, the residuals for suspended solids and total phosphorus both show a significant reduction after accounting for natural variability. It is possible that the other sites will also show statistically significant reductions in suspended solids and total phosphorus if additional BMPs are implemented.

\section{INTRODUCTION}

In October, 1989, the U.S. Geological Survey (USGS) began a watershed-management evaluation monitoring program in cooperation with the Wisconsin Department of Natural Resources (WDNR). The overall objective of each individual project in the program is to determine if the water quality of the receiving stream has improved as a result of the implementation of landmanagement practices in the watershed. This is accomplished through monitoring of water chemistry and ancillary variables before best-management practices (BMPs) are implemented, during implementation, and after watershed-management practices have been completely implemented. The period before BMP implementation is termed "pre-BMP," the period during active implementation is termed "transitional," and the period after complete implementation is termed "postBMP."

Eight rural and four urban sites were selected jointly by WDNR and USGS for detailed evaluation monitoring. The sites were selected using a variety of criteria, including likelihood for significant BMP implementation, relatively small watershed size [less than 50 square miles $\left(\mathrm{mi}^{2}\right)$ ], feasibility for accurate stream gaging, etc. Locations of the sites are shown in figure 1.

The county Land Conservation Departments (LCDs) and the WDNR have identified nonpoint sources of pollution in each rural watershed. This infor- 
mation was used to select sites that are eligible for partial funding of BMP implementation. The LCDs are in the process of contacting landowners to request that they implement the appropriate BMPs for stream waterquality improvement. This is a voluntary program that may result in varied success depending largely upon the percentage of landowners that implement the recommended BMPs.

The four urban sites were selected from the watersheds identified in the Priority Watershed program. The WDNR and each city have identified nonpoint sources of pollution in the urban watersheds. Nonpoint-source pollution reduction goals have been set, but a specific plan identifying the type and location of BMPs needed to achieve these goals has not been defined.

This report, the fifth in a series of progress reports, provides a summary of data collected for the watershedmanagement evaluation monitoring program in Wisconsin. The following topics are addressed:

(1) land-use and BMP inventories, including a discussion of data-collection efforts and the status of BMP implementation; (2) stream water-quality data, including a discussion of data-collection efforts, a comparison of annual loads for the rural sites, and a discussion of dissolved-oxygen data collection; (3) urban load regression analysis, including a brief discussion of the statistical approach for trend detection and presentation and discussion of preliminary pre-BMP regressions for the urban sites; and (4) transitional data analysis, including regression results and a preliminary trend assessment for some of the rural sites. For sections presenting ongoing data-collection efforts, data collected during water year 1999 (October 1997 through September 1999) are summarized and, if appropriate, implications for future data-collection efforts are discussed.

\section{LAND-USE AND BEST-MANAGEMENT PRACTICE INVENTORIES}

Inventories of the eight rural watersheds began in 1992 to provide information on land-use and land-treatment changes in support of the whole-stream evaluation monitoring effort. Detailed descriptions of each watershed and the program are provided in Rappold and others (1997) and Wierl and others (1996). This section summarizes the land-use-inventory program activities through the 1999 water year and planned activities for the 2000 water year.

\section{Activities through 1999 Water Year}

Annual updates of BMP implementation status have been conducted since 1992 . The tracking system is in a Geographic Information System (GIS) data base that also provides spatial layers of land use and land cover. The tracking method and details about the data base are described in Rappold and others (1997).

In 1998 the inventory team used land-use information from the Otter Creek watershed and appropriate models to estimate phosphorus loads from barnyards and cropland areas. Model parameters were determined using a farm-field characteristic layer from the GIS data base. Soils from specific sites were collected for particle-size analysis using the method described in Dong and others (1979). A detailed description of the model results and methods for locating significant sources of phosphorus, which could be used to target resources, is reported in Wierl and others (1998).

In 1999 Brewery and Garfoot Creek watersheds completed the post-BMP period achieving the majority of the goals set by the WDNR and the local Land Conservation Department (table 1). Additional practices may be implemented in the next several years but the majority of sources were controlled by the practices already implemented. Land-use tracking was discontinued in 1999 because the post-monitoring phase was considered completed.

Tracking of the Otter Creek, Bower Creek, Eagle Creek, and Joos Valley Creek watersheds will continue until the post-monitoring phases have been completed (table 1). Rattlesnake Creek and Kuenster Creek have not been tracked for several years because of lack of BMP implementation and discontinuation of WDNR funding for BMP implementation.

\section{Activities Planned for Water Year 2000}

The following land-use and BMP monitoring activities are planned for water year 2000:

1. Complete an inventory of agricultural crops being grown in each watershed;

2. Complete an inventory of BMPs implemented in each watershed; and

3. Assess if watersheds are going into the postmonitoring phase. 


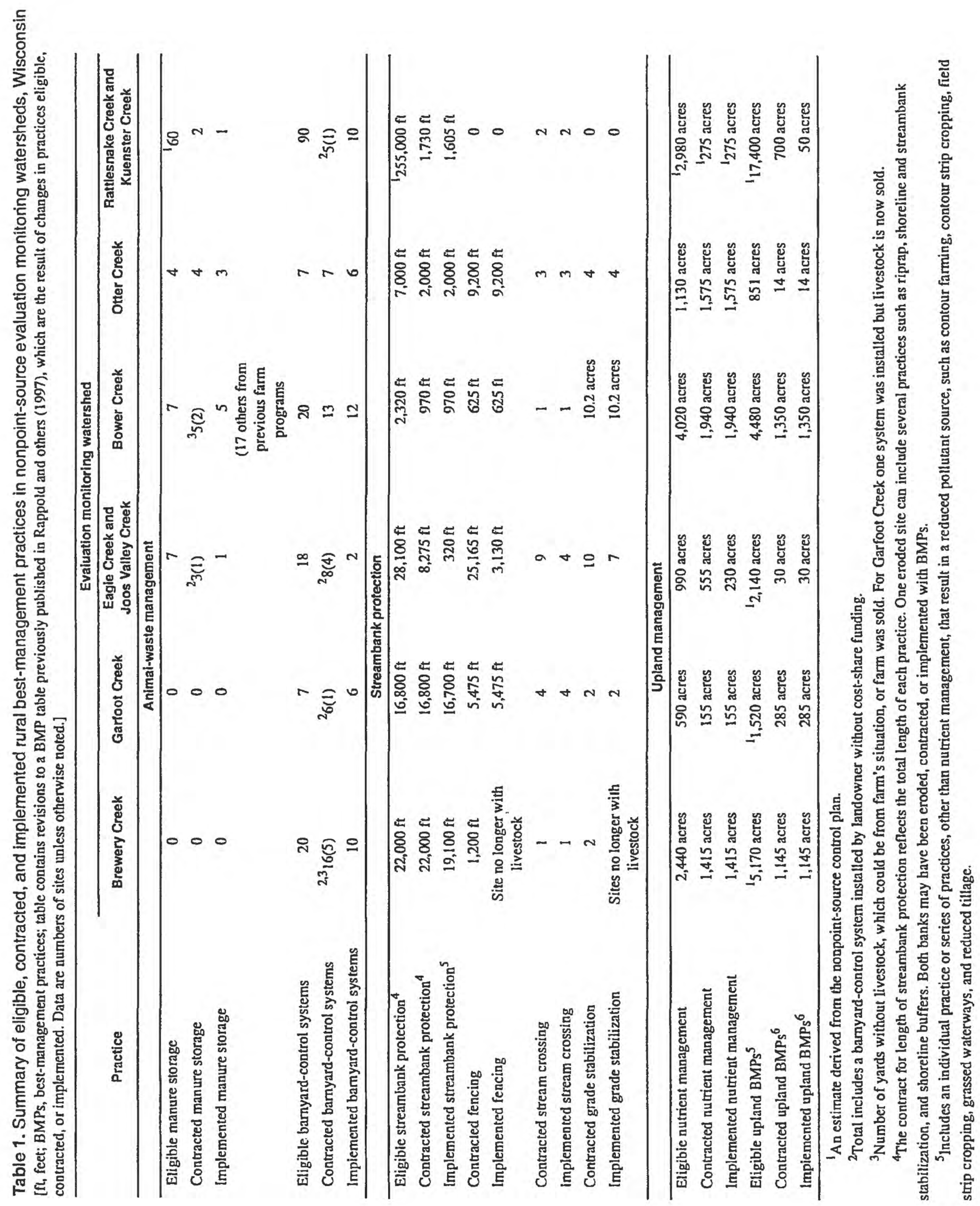




\section{SELECTED STREAM-WATER QUALITY DATA}

Stream-water quality data are summarized in three parts in this section. The first part discusses the availability of water-quality data, including loads for stormflow periods. The second part discusses specific data compiled at rural sites, and includes (1) a graph of the number of storms and estimated constituent loads, and (2) annual constituent loads for the specific period of record at each site. The third part discusses dissolvedoxygen data collection at the rural watershed evaluation sites.

\section{Availability of Stream-Water Quality Data}

Precipitation, streamflow volume, and storm loads for several water-quality constituents have been computed for all monitored storm periods and summarized for rural sites (appendix). The rural data are summarized through water year 1998. Data collection was suspended on July 1, 1996 for four of the rural sites (Eagle, Joos Valley, Rattlesnake and Kuenster Creeks) pending continued implementation of the watershed plans.

Accordingly, data in the appendix are complete through the end of the appropriate data-collection period for these four sites. Daily loads for selected constituents and discrete concentration data for the samples used to calculate these loads are published in the USGS annual water-data reports for Wisconsin (Holmstrom and others, 1986-87; Holmstrom and Erickson, 1989; Holmstrom and others, 1990-98). Maximum, minimum, and mean dissolved-oxygen concentrations and water temperatures also are published in these annual reports. All data collected at the evaluation-monitoring sites are available by request from the USGS office in Middleton, Wisconsin.

In addition to the data published in various reports, electronic retrievals of the data are possible through the world-wide-web. Historical streamflow data is available by connecting to the following uniform resource locator (URL):

\section{http://water.usgs.gov/nwis-w/WI/index.cgi}

Instantaneous constituent concentrations as well as storm-period data (precipitation, streamflow volume, and constituent loads) are available through the District Office.

\section{Summary of Loads at Rural Stream Sites}

Water-quality monitoring at the eight rural evaluation monitoring sites (fig. 1) continued at selected sites with sampling during baseflow and stormflow periods. Instantaneous water-quality data were used in conjunction with continuous streamflow data to estimate total constituent loads for stormflow periods. Suspended sediment or suspended solids, total phosphorus, and ammonia-nitrogen loads were computed at the eight rural evaluation monitoring sites. For Brewery and Garfoot Creeks, suspended-sediment loads were computed in a manner consistent with pre-BMP data collected in a previous study; for all other sites, suspended-solids loads were computed. Ammonia-nitrogen loads were not computed for sites on Otter and Bower Creeks. The rural storm-load data will be used to evaluate the effect of BMPs on stream-water quality. Previous research using the rural regression analysis (Walker and Graczyk, 1993; Walker, 1994) has shown theoretically that the minimum detectable change at rural sites reaches a minimum at roughly 40 total storms; this corresponds to 20 pre-BMP and 20 post-BMP storms for a balanced data collection. The number of pre-BMP, transitional, and post-BMP storms for which loads were calculated at rural evaluation monitoring sites for the period of record ending in the 1998 water year is shown in figure 2.

The pre-implementation, transitional, and post implementation periods have been selected for all eight rural evaluation monitoring sites (table 2). Loads for a sufficient number of storms are available for the preBMP implementation period at all of the eight rural evaluation monitoring watersheds (fig. 2). At two of the watersheds (Brewery and Garfoot Creeks), storm data has been collected during the post-BMP implementation period (fig. 2). For the period April 1, 1997 through September 30, 1998, loads have been calculated for 17 post-BMP storms at Garfoot Creek, which will be compared to the storm loads calculated during the preimplementation period. For the period October 1, 1996 through September 30,1998, loads have been calculated for 19 post-BMP storms at Brewery Creek, which will be compared to the storm loads computed during the pre-implementation period. Data collection at Bower, Eagle, Joos Valley, Rattlesnake, and Kuenster Creeks has been suspended. At Eagle and Joos Valley Creeks, the sign-up period has been extended so it was prudent to suspend monitoring until a sufficient number of BMPs have been installed. Implementation of BMPs 


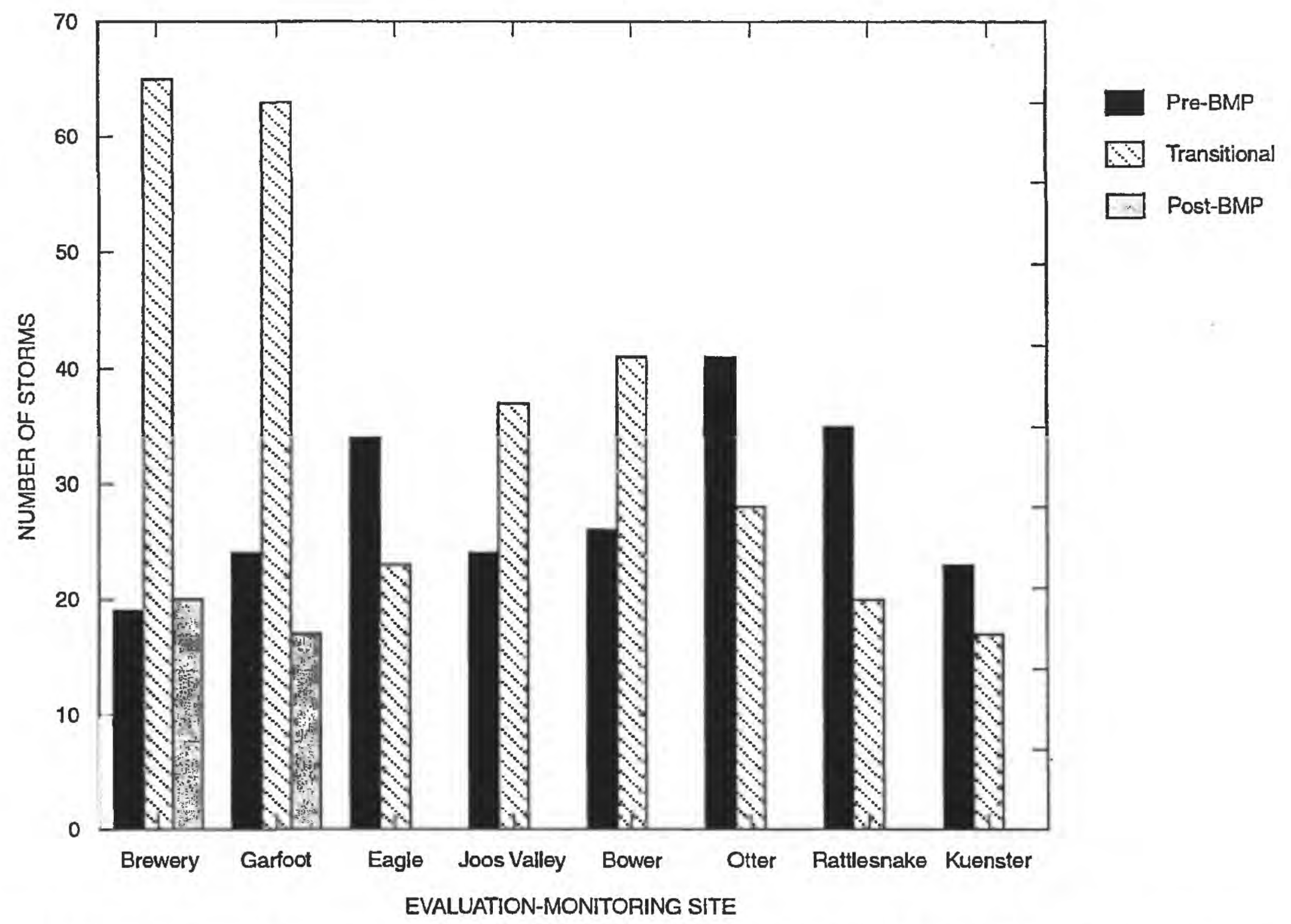

Figure 2. Number of storms through water year 1998 for which loads were calculated at the evaluation-monitoring sites. (Storms are tabulated for the period before implementation of best-management practices (pre-BMP), during installation (transitional) and after completion of BMP installation (post-BMP).)

in Eagle and Joos Valley Creeks will not be completed until the year 2000 or after (table 2). In Rattlesnake and Kuenster Creeks, the post-BMP implementation began in 1996 and 1998 respectively (table 2). At this time very few landowners in these two basins have participated in the cost-sharing program. With few landowners participating and not many BMPs installed, the chances of observing a statistically detectable change in water quality will be slight. Monitoring will begin again if sufficient BMPs have been installed. At all four of these sites there has been a sufficient number of samples taken during pre-BMP storms and additional pre-BMP storm samples are not needed.

Annual loads of suspended sediment or suspended solids and total phosphorus were determined at each of the eight rural evaluation monitoring sites (fig. 1) for the period of data collection through the 1996 water year. The annual loads are summarized in table 3 . For the four sites that had complete data collection in water year 1996 (Garfoot, Brewery, Otter, and Kuenster
Creeks) the suspended sediment or solids and total phosphorus load were less than the mean for the data collection period (table 3 ). The suspended solids and total phosphorus loads at Otter Creek were the lowest for the 5-year data-collection period (table 3). The total streamflow for water year 1996 was also the lowest during this period, which may account for the low constituent loads in water year 1996 rather than an improvement in water quality that may have resulted from BMP implementation.

\section{Dissolved Oxygen}

Dissolved-oxygen data were collected continuously at five rural sites: Garfoot Creek, Black Earth Creek at South Valley Road, Otter Creek, Rattlesnake Creek, and Kuenster Creek (fig. 1). Dissolved oxygen data were collected during open water periods; all dissolved-oxygen meters were removed during the winter. 
Table 2. Pre-implementation, transitional, and post-implementation periods for the rural evaluation monitoring watersheds

\begin{tabular}{llll}
\hline $\begin{array}{c}\text { Rural evaluation } \\
\text { monitoring } \\
\text { watersheds }\end{array}$ & $\begin{array}{c}\text { Pre-BMP } \\
\text { implementation } \\
\text { period }\end{array}$ & Transitional period & $\begin{array}{c}\text { Post-BMP } \\
\text { implementation } \\
\text { period }\end{array}$ \\
\hline Brewery Creek & Prior to 10/31/89 & $11 / 01 / 89$ to 07/30/96 & After 09/30/96 \\
Garfoot Creek & Prior to 09/30/90 & $10 / 01 / 90$ to 03/31/97 & After 04/01/97 \\
Eagle Creek & Prior to 09/30/93 & $10 / 01 / 93$ to 09/30/00 & After 10/01/00 \\
Joos Valley Creek & Prior to 09/30/92 & $10 / 01 / 92$ to 09/30/00 & After $10 / 01 / 00$ \\
Otter Creek & Prior to 09/30/93 & $10 / 01 / 93$ to 09/30/97 & After $10 / 01 / 97$ \\
Bower Creek & Prior to $11 / 30 / 92$ & $12 / 01 / 92$ to 09/30/99 & After 10/01/99 \\
Rattlesnake Creek & Prior to 05/31/93 & $06 / 01 / 93$ to 09/30/96 & After 10/01/96 \\
Kuenster Creek & Prior to 06/30/94 & $07 / 01 / 94$ to 09/30/98 & After 10/01/98 \\
\hline
\end{tabular}

It is difficult to determine if the water quality as measured by dissolved-oxygen concentration has improved. Because dissolved-oxygen concentration in the stream is a function of other factors such as atmospheric pressure and water temperature, any changes in minimum dissolved-oxygen concentration may be a result of these atmospheric inputs rather than implementation of best-management practices.

Maximum, minimum, and mean concentrations of dissolved oxygen for each of the five rural sites for water years 1990-96 are listed in table 4. The maximum dissolved oxygen was $20.0 \mathrm{mg} / \mathrm{L}$ at Otter Creek in water year 1996 (table 4). The minimum dissolved oxygen was $0.00 \mathrm{mg} / \mathrm{L}$ at Rattlesnake Creek in water year 1991. The three warm-water streams (Rattlesnake, Kuenster and Otter Creeks) had minimum dissolved-oxygen concentrations less than $1.0 \mathrm{mg} / \mathrm{L}$. Dissolved-oxygen concentrations below $1.0 \mathrm{mg} / \mathrm{L}$ for extended periods of time are lethal to fish and other aquatic organisms. At the two cold-water streams (Garfoot and Black Earth Creek) the minimum dissolved oxygen was not less than $1.0 \mathrm{mg} / \mathrm{L}$ (table 4). The minimum dissolved oxygen concentration at Garfoot Creek was $1.3 \mathrm{mg} / \mathrm{L}$ in water year 1992. The minimum dissolved-oxygen concentration at Black Earth Creek was $3.9 \mathrm{mg} / \mathrm{L}$ in water year 1991 (table 4).

The State of Wisconsin has different water quality standards for dissolved oxygen based on stream water temperatures. For warm-water streams with maximum water temperature above $24.0^{\circ}$ Centigrade (C) the minimum dissolved-oxygen concentration required is 5.0 milligrams per liter ( $\mathrm{mg} / \mathrm{L}$ ) (Wisconsin Administrative Code, 1992). For cold-water streams with a maximum water temperature below $24.0^{\circ} \mathrm{C}$, the minimum dissolved-oxygen concentration required is $6.0 \mathrm{mg} / \mathrm{L}$ (Wisconsin Administrative Code, 1992). The number of days the dissolved-oxygen concentrations were less than these standards and the total number of days dissolved-oxygen concentrations were monitored during water year 1990-96 are listed in table 5. At Garfoot Creek the number of days dissolved-oxygen concentrations were less than $6.0 \mathrm{mg} / \mathrm{L}$ decreased in 1992 through water year 1994 (table 5). The number of days that the State standard was violated at Garfoot Creek was 22 in water year 1992 but in 1994 there was only 1 day the standard was violated. During water years 1995 and 1996, the State standard was violated on 2 and 3 days, respectively. At Black Earth Creek there were no violations of the State standard in water year 1996, in contrast to water year 1995 during which there were 41 days when the minimum dissolved-oxygen concentration was less than the State standard.

At the warm-water streams, Otter Creek had 62 violations of the State standard in water year 1995 but in water year 1996 there were only 7 violations (table 5). This was the fewest violations of the State standard during the years this site has been monitored (table 5).

The return period in days and the continuous time that the dissolved-oxygen concentration is less than the State standards also may affect aquatic organisms. A frequency analysis was done to determine the return period in days when the instantaneous dissolved-oxygen concentration would be less than the State of Wisconsin standard for one hour. In 1996 at Garfoot Creek the dissolved-oxygen concentration was less than $6.0 \mathrm{mg} / \mathrm{L}$ for one continuous hour once every 21 days or about 7 times during the summer period of May through September (fig. 3). This is an improvement from water years 1990,1992, and 1994 but not from water years 1991 and 1995 (fig. 3). In water year 1991 the dis- 
Table 3. Summary of annual suspended-sediment or suspendedsolids loads, total phosphorus loads, and streamflow at Wisconsin evaluation monitoring sites, water years $1985-86$ and $1990-96$

$\left[--\right.$, not computed; lb, pound; $\mathrm{mi}^{2}$, square miles; $\mathrm{Mft}^{3}$, million cubic feet; 05406470 , station number]

\begin{tabular}{|c|c|c|c|}
\hline Water year & $\begin{array}{l}\text { Suspended-sediment } \\
\text { or suspended- } \\
\text { solids load } \\
\text { (tons) }\end{array}$ & $\begin{array}{l}\text { Total phosphorus } \\
\text { load } \\
\text { (ib) }\end{array}$ & $\begin{array}{c}\text { Total } \\
\text { streamflow } \\
\left(\mathrm{Mft}^{3}\right)\end{array}$ \\
\hline \multicolumn{4}{|c|}{ Brewery Creek-05406470 (contributing area $7.7 \mathrm{mi}^{2}$ ) } \\
\hline 1985 & 894 & 4,840 & 86.0 \\
\hline${ }^{1} 1986$ & $a_{279}$ & $1_{1,590}$ & ${ }^{1} 75.0$ \\
\hline 1990 & 521 & 3,850 & 36.5 \\
\hline 1991 & 45.3 & 700 & 18.4 \\
\hline 1992 & 180 & 1,960 & 28.4 \\
\hline 1993 & 2,640 & 10,700 & 135 \\
\hline 1994 & 792 & 3,420 & 125 \\
\hline 1995 & 525 & 1,390 & 79.6 \\
\hline 1996 & 1,010 & 4,620 & 83.8 \\
\hline${ }^{2}$ Mean & ${ }^{2} 800$ & 23,840 & 272.7 \\
\hline \multicolumn{4}{|c|}{ Garfoot Creek—05406491 (contributing area $5.39 \mathrm{mi}^{2}$ ) } \\
\hline 1985 & 462 & 3,060 & 166 \\
\hline${ }^{1} 1986$ & $1_{441}$ & $1^{1}, 450$ & ${ }^{t} 156$ \\
\hline 1990 & 337 & 2,850 & 100 \\
\hline 1991 & 290 & 2,100 & 103 \\
\hline 1992 & 200 & 2,230 & 127 \\
\hline 1993 & 1,160 & 7,080 & 243 \\
\hline 1994 & 238 & 1,720 & 155 \\
\hline 1995 & 330 & 1,749 & 171 \\
\hline 1996 & 784 & 3,360 & 175 \\
\hline${ }^{2}$ Mean & 2431 & ${ }^{2} 2,970$ & ${ }^{2} 152$ \\
\hline \multicolumn{4}{|c|}{ Eagle Creek-05378185 (contributing area $14.3 \mathrm{mi}^{2}$ ) } \\
\hline${ }^{1} 1990$ & $1_{4,340}$ & 29,460 & 384.5 \\
\hline 1991 & 6,580 & 11,600 & 244 \\
\hline 1992 & 3,920 & 8.900 & 287 \\
\hline 1993 & 7,960 & 17,900 & 425 \\
\hline 1994 & 5,690 & 11,600 & 370 \\
\hline${ }^{1} 1995$ & ${ }^{1} 5,530$ & ${ }^{1} 11,200$ & $1_{310}$ \\
\hline 1996 & 12,380 & 16,030 & $1_{228}$ \\
\hline${ }^{2}$ Mean & ${ }^{2} 6,040$ & ${ }^{2} 12,500$ & 2331 \\
\hline \multicolumn{4}{|c|}{ Joos Valley Creek-05378183 (contributing area $5.09 \mathrm{mi}^{2}$ ) } \\
\hline${ }^{a} 1990$ & ${ }^{1} 1,150$ & 3.080 & $1_{28.3}$ \\
\hline 1991 & 1,470 & 3,160 & 95.6 \\
\hline 1992 & 1,390 & 3,880 & 127 \\
\hline 1993 & 2,900 & 6,440 & 183 \\
\hline
\end{tabular}


Table 3. Summary of annual suspended-sediment or suspendedsolids loads, total phosphorus loads, and streamflow at Wisconsin evaluation monitoring sites, water years 1985-86 and 1990-96-Continued [--, not computed; lb, pound; $\mathrm{mi}^{2}$, square miles; $\mathrm{Mft}^{3}$, million cubic feet; 05406470, station number]

\begin{tabular}{|c|c|c|c|}
\hline Water year & $\begin{array}{l}\text { Suspended-sediment } \\
\text { or suspended- } \\
\text { solids load } \\
\text { (tons) }\end{array}$ & $\begin{array}{l}\text { Total phosphorus } \\
\text { load } \\
\text { (lb) }\end{array}$ & $\begin{array}{c}\text { Total } \\
\text { streamflow } \\
\left(\mathrm{Mft}^{3}\right)\end{array}$ \\
\hline \multicolumn{4}{|c|}{ Joos Valley Creek-05378183 (contributing area $5.09 \mathrm{mi}^{2}$ )-Continued } \\
\hline 1994 & 2,100 & 4,990 & 162 \\
\hline${ }^{1} 1995$ & ${ }^{1} 6,230$ & 10,100 & ${ }^{1} 139$ \\
\hline 1996 & ${ }^{1} 1,070$ & 2,510 & ${ }^{1} 1,120$ \\
\hline${ }^{2}$ Mean & $z_{1,970}$ & 4,620 & ${ }^{2} 142$ \\
\hline \multicolumn{4}{|c|}{ Bower Creek-04085119 (contributing area $14.8 \mathrm{mi}^{2}$ ) } \\
\hline 1991 & 718 & 9,480 & 217 \\
\hline 1992 & 1,450 & 10,800 & 200 \\
\hline 1993 & 11,100 & 26,600 & 584 \\
\hline 1994 & 2,420 & 9,143 & 144 \\
\hline${ }^{1} 1995$ & ${ }^{1} 0.01$ & ${ }^{1} 7.8$ & ${ }^{1} 0.60$ \\
\hline 1996 & ${ }^{1} 1,540$ & ${ }^{1} 7,660$ & ${ }^{1} 384$ \\
\hline${ }^{2}$ Mean & $z_{3,920}$ & ${ }^{2} 14,000$ & ${ }^{2} 286$ \\
\hline \multicolumn{4}{|c|}{ Otter Creek-040857005 (contributling area $9.5 \mathrm{mi}^{2}$ ) } \\
\hline 1991 & 308 & 2,490 & 181 \\
\hline 1992 & 285 & 2,180 & 202 \\
\hline 1993 & 867 & 5,580 & 343 \\
\hline 1994 & 216 & 3,060 & 193 \\
\hline 1995 & 86.0 & 810 & 107 \\
\hline 1996 & 180 & 1,990 & 187 \\
\hline Mean & 352 & 2,820 & 205 \\
\hline \multicolumn{4}{|c|}{ Rattlesnake Creek-05413449 (contrlbuting area $42.4 \mathrm{mi}^{2}$ ) } \\
\hline 1992 & 5,870 & 30,600 & 213 \\
\hline 1993 & 35,500 & 156,000 & 427 \\
\hline 1994 & 8,480 & 34,800 & 245 \\
\hline 1995 & -- & - & 693 \\
\hline Mean & 16,600 & 73,800 & 395 \\
\hline \multicolumn{4}{|c|}{ Kuenster Creek—054134435 (contrlbuting area $9.59 \mathrm{mi}^{2}$ ) } \\
\hline 1993 & 9,690 & 38,000 & 385 \\
\hline 1994 & 3,180 & 9,180 & 199 \\
\hline 1995 & 347 & 2,300 & 133 \\
\hline 1996 & ${ }^{1} 470$ & ${ }^{1} 4,680$ & ${ }^{1} 135$ \\
\hline Mean & 24,410 & ${ }^{2} 16,500$ & ${ }^{2} 239$ \\
\hline
\end{tabular}

'Partial year of the data collected.

${ }^{2}$ Mean does not include partial years. 
Table 4. Summary of dissolved-oxygen concentration in surface water at Wisconsin watershed-management evaluationmonitoring sites, water years 1990-96

[Concentrations are in milligrams per liter;--, no data]

\begin{tabular}{|c|c|c|c|c|c|c|}
\hline Water year & Maximum & Minimum & Mean & Maximum & Minimum & Mean \\
\hline & \multicolumn{3}{|c|}{ Garloot Creek } & \multicolumn{3}{|c|}{ Rattiesnake Creek } \\
\hline 1990 & 17.4 & 1.5 & 9.4 & 16.7 & 0.05 & 9.2 \\
\hline 1991 & 14.6 & 4.7 & 9.5 & 16.8 & .00 & 9.6 \\
\hline 1992 & 13.7 & 1.3 & 8.8 & 16.3 & .09 & 8.8 \\
\hline 1993 & 13.1 & 4.0 & 9.1 & 14.9 & 4.8 & 9.6 \\
\hline 1994 & 12.3 & 4.2 & 9.6 & 17.3 & 4.8 & 9.1 \\
\hline 1995 & 13.9 & 5.1 & 9.1 & 13.3 & 3.1 & 8.5 \\
\hline \multirow[t]{2}{*}{1996} & 15.2 & 4.5 & 9.8 & 17.5 & 2.5 & 8.7 \\
\hline & \multicolumn{3}{|c|}{ Biack Earth Creek At South Vailey Road } & \multicolumn{3}{|c|}{ Kuenster Creek } \\
\hline 1990 & 17.1 & 4.8 & 9.6 & -- & - & - \\
\hline 1991 & 18.3 & 3.9 & 9.7 & -- & - & -- \\
\hline 1992 & 18.3 & 4.3 & 9.7 & 19.9 & .80 & 8.5 \\
\hline 1993 & 13.5 & 5.2 & 9.2 & 16.2 & .50 & 9.5 \\
\hline 1994 & 16.3 & 5.0 & 9.3 & 19.0 & 2.0 & 8.8 \\
\hline 1995 & 16.1 & 4.4 & 9.0 & 16.0 & 3.8 & 8.7 \\
\hline \multirow[t]{2}{*}{1996} & 17.1 & 6.5 & 9.9 & 15.3 & 3.5 & 9.0 \\
\hline & \multicolumn{3}{|c|}{ Otter Creek } & & & \\
\hline 1990 & 16.0 & .8 & 7.3 & & & \\
\hline 1991 & 19.1 & 3.2 & 9.1 & & & \\
\hline 1992 & 17.6 & .2 & 9.7 & & & \\
\hline 1993 & 16.5 & 3.6 & 8.8 & & & \\
\hline 1994 & 16.7 & 3.7 & 8.4 & & & \\
\hline 1995 & 17.4 & 2.6 & 7.8 & & & \\
\hline 1996 & 20.0 & 4.5 & 9.0 & & & \\
\hline
\end{tabular}

solved-oxygen concentration was less than $6.0 \mathrm{mg} / \mathrm{L}$ for one continuous hour once every 48 days or three times a summer. In 1995 the dissolved-oxygen concentration was less than $6.0 \mathrm{mg} / \mathrm{L}$ for one continuous hour once every 53 days or three times during the summer period (fig. 3). The frequency analysis may show a slight improvement in water quality based on dissolved-oxy gen concentration in water years 1990, 1992, and 1994 compared to 1996. There would be no improvement in water quality if the comparison is made using water years 1991,1993 , and 1995 to 1996 . It could be interpreted that the water quality has improved on the basis of the dissolved-oxygen minimum concentrations shown in table 5). The minimum dissolved-oxygen concentration was less than $2.0 \mathrm{mg} / \mathrm{L}$ in water year 1990 and 1992 but in water year 1991 and 1993 through 1996, the minimum dissolved-oxygen concentration was $4.0 \mathrm{mg} / \mathrm{L}$ or higher at Garfoot Creek (table 4). The number of days that the instantaneous minimum dissolved-oxygen concentration was less than $6.0 \mathrm{mg} / \mathrm{L}$ was one, two, and three days in the 1994 through 1996 water years, respectively. The maximum number of days the instantaneous dissolved oxygen was less than the State standard was 22 in water year 1992 (table 5).

In water year 1991, 1993 and 1994 at Otter Creek the dissolved-oxygen concentration was less than $5.0 \mathrm{mg} / \mathrm{L}$ for one continuous hour once every 10 days or about 15 times during the 153 day summer period (fig. 4). In water year 1992, the dissolved-oxygen concentration was less than $5.0 \mathrm{mg} / \mathrm{L}$ for one continuous hour once every 20 days or about 8 times during the summer period (fig. 4). In 1995, the dissolved-oxygen concentration was less than $5.0 \mathrm{mg} / \mathrm{L}$ for one continuous hour once every 3 days or about 51 times during the summer period (fig. 4). In 1996, however, the dissolved-oxygen concentration was less than $5.0 \mathrm{mg} / \mathrm{L}$ for one continuous hour once every 17 days or about nine times during the summer period. This is an improvement from water year 1995 but not from water year 1992.

As at Garfoot Creek, it may be difficult to determine if the water quality has improved as measured by 
Table 5. Number of days that dissolved-oxygen concentration in surface water was less than the State of Wisconsin standard at selected stream sites during water years 1990-96

[mg/L, milligrams per liter; ${ }^{\circ} \mathrm{C}$, degrees centigrade]

\begin{tabular}{|c|c|c|c|c|}
\hline Water year & $\begin{array}{l}\text { Number of days } \\
\text { dissolved } \\
\text { oxygen } \\
\text { concentration } \\
\text { was iess than } \\
6 \mathrm{mg} / \mathrm{h}\end{array}$ & $\begin{array}{l}\text { Total number of } \\
\text { days dissolved } \\
\text { oxygen was } \\
\text { monitored }\end{array}$ & $\begin{array}{l}\text { Number of days } \\
\text { dissolved } \\
\text { oxygen } \\
\text { concentration } \\
\text { was iess than } \\
5 \mathrm{mg} / \mathrm{L}\end{array}$ & $\begin{array}{c}\text { Total number of } \\
\text { days dissolved } \\
\text { oxygen was } \\
\text { monitored }\end{array}$ \\
\hline & \multicolumn{2}{|c|}{ Coidwater streams ${ }^{1}$} & \multicolumn{2}{|c|}{ Warmwater streams ${ }^{2}$} \\
\hline & \multicolumn{2}{|c|}{ Garfoot Creek } & \multicolumn{2}{|c|}{ Otter Creek } \\
\hline 1990 & 12 & 183 & 14 & 43 \\
\hline 1991 & 9 & 249 & 25 & 202 \\
\hline 1992 & 22 & 169 & 23 & 206 \\
\hline 1993 & 11 & 132 & 18 & 142 \\
\hline 1994 & 1 & ${ }^{3} 79$ & 30 & 150 \\
\hline 1995 & 2 & 118 & 62 & 159 \\
\hline \multirow[t]{2}{*}{1996} & 3 & 137 & 7 & 140 \\
\hline & \multicolumn{2}{|c|}{ Black Earth Creek at South Valley Road } & \multicolumn{2}{|c|}{ Rattlesnake Creek } \\
\hline 1990 & 21 & 182 & 21 & 229 \\
\hline 1991 & 49 & 217 & 14 & 206 \\
\hline 1992 & 21 & 158 & 35 & 161 \\
\hline 1993 & 4 & 157 & 1 & 156 \\
\hline 1994 & 3 & 115 & 2 & 164 \\
\hline 1995 & 41 & 144 & 9 & 141 \\
\hline \multirow[t]{2}{*}{1996} & 0 & 116 & 4 & 459 \\
\hline & & & \multicolumn{2}{|c|}{ Kuenster Creek } \\
\hline 1992 & & & 53 & 171 \\
\hline 1993 & & & 4 & 141 \\
\hline 1994 & & & 16 & 133 \\
\hline 1995 & & & 10 & 142 \\
\hline 1996 & & & 5 & ${ }^{4} 40$ \\
\hline
\end{tabular}

${ }^{1}$ Cold-water streams typically have maximum stream-water temperature less than $24^{\circ} \mathrm{C}$.

${ }^{2}$ Warma-water streams typically have maximum stream-water temperature greater than $24^{\circ} \mathrm{C}$.

${ }^{3}$ Partial year April-May and August-September.

${ }^{4}$ Data collection June and July only. Data collection discontinued on June 30, 1996.

dissolved-oxygen concentration at Otter Creek. The number of days that the dissolved-oxygen concentration was less than the State standard were the fewest in water year 1996 (table 5). In addition, the minimum dissolved-oxygen concentration measured was $4.5 \mathrm{mg} / \mathrm{L}$ in 1996, which is the highest minimum dissolved-oxygen since data collection began in 1990 (table 4). In the 1990 and 1992 water years the minimum dissolvedoxygen concentration was less than 1.0 but in the 1995 water year, the minimum dissolved-oxygen concentration minimum was 2.6 (table 4). The number of days the dissolved-oxygen concentration for one continuous hour was less than the State standard was fewer in water year 1996 as compared to water year 1995 . Water year 1995 had the most days below the State standard for one continuous hour. Water year 1992, however, had the fewest days below 5.0 for one continuous hour. No bestmanagement practices were implemented before the 1993 water year. 


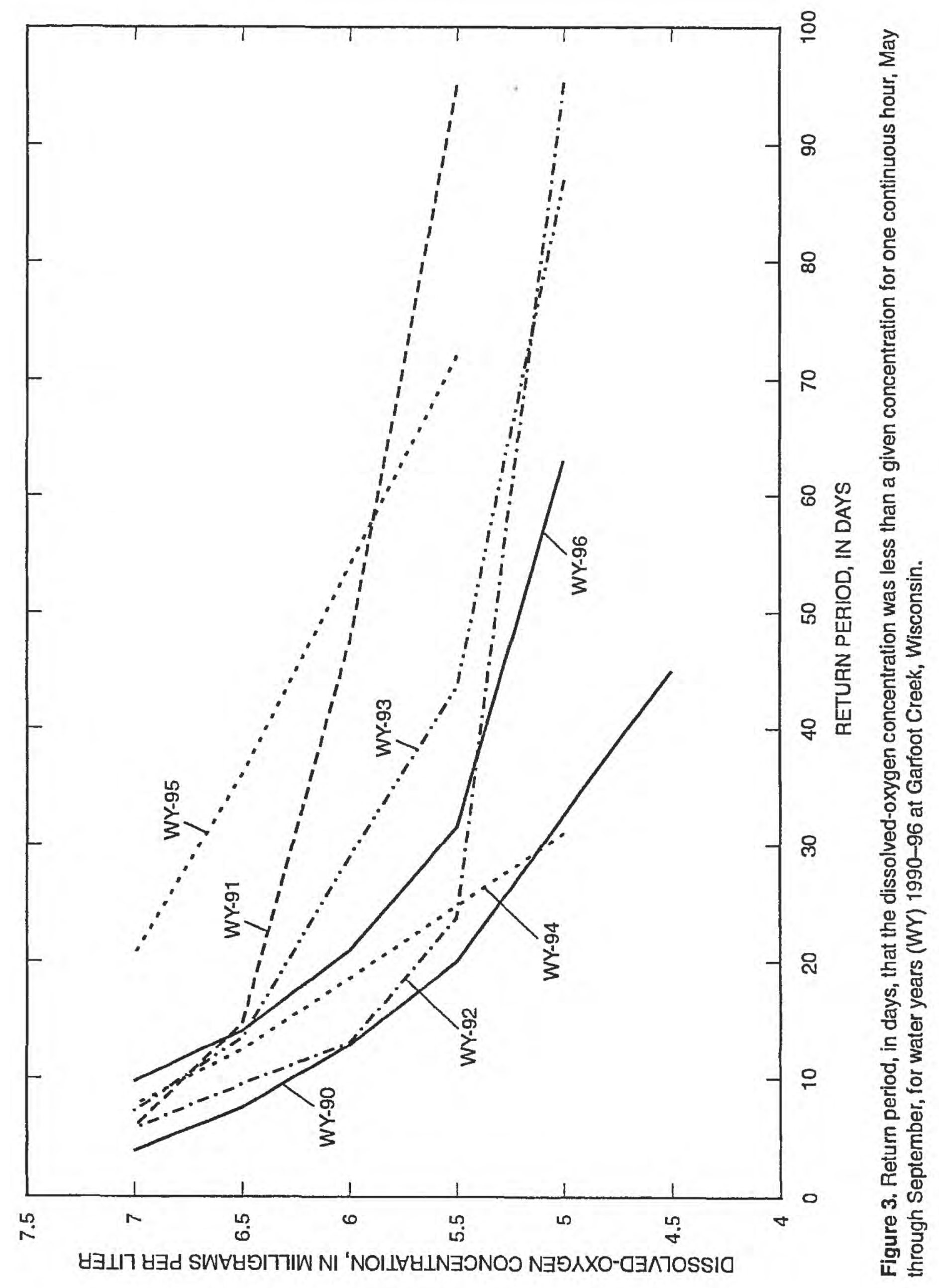




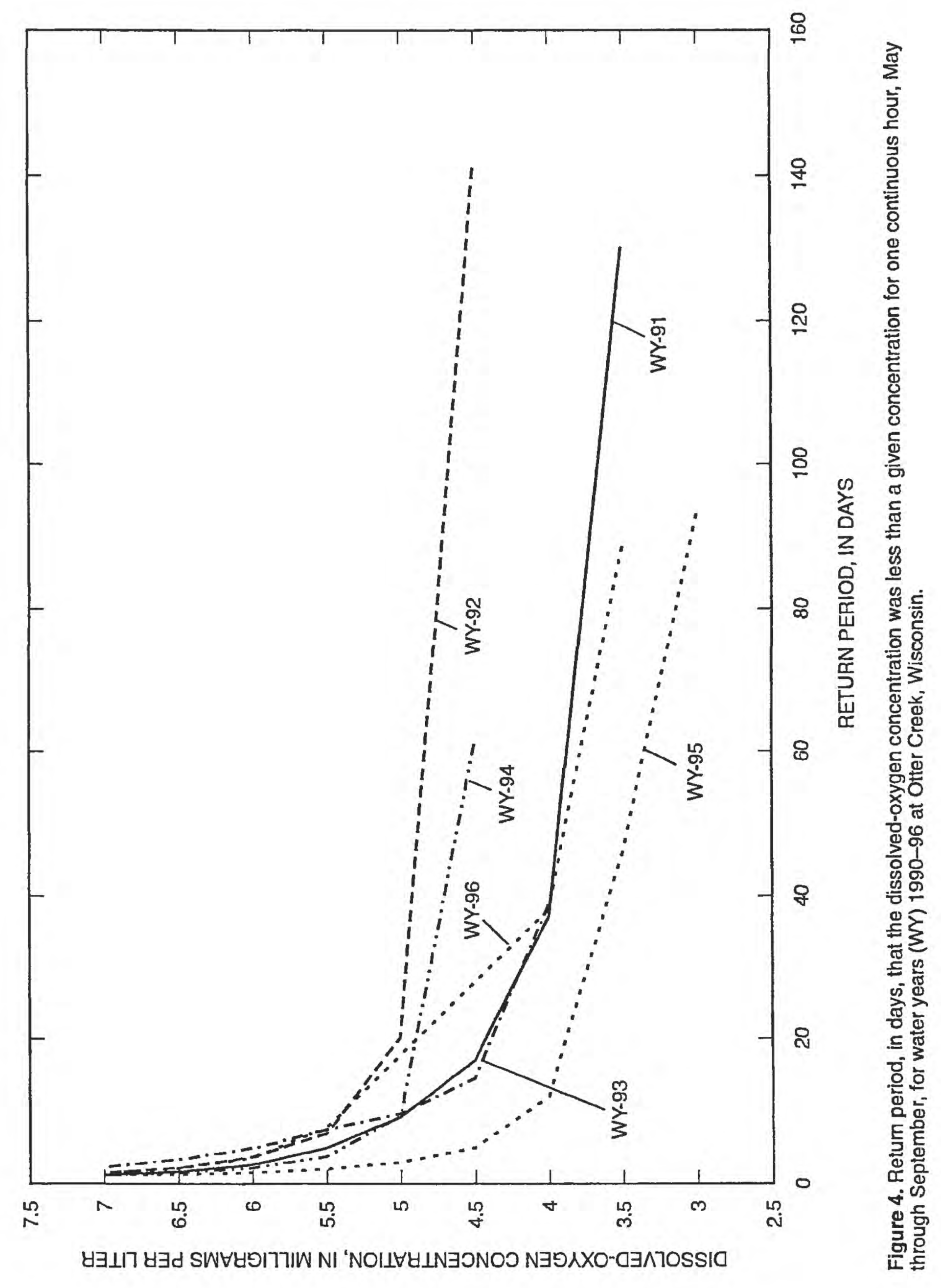




\section{Monitoring Plan for Water Year 2000}

The following water-quality-monitoring activity is planned for water year 2000:

Continue collection of rural stormflow samples for determination of suspendedsolids or suspended-sediment, totalphosphorus and ammonia-nitrogen loads at Otter Creek.

\section{ANALYSIS OF PRE-BMP CONSTITUENT LOADS AT URBAN STREAM SITES}

The goal of the evaluation monitoring program is to determine if the implementation of BMPs has resulted in an improvement in the water quality of the stream. Previous research has identified an appropriate statistical approach that can be used to determine if statistically significant changes have occurred (Walker, 1994). The general approach is to compare constituent loads in stormflow during pre-BMP conditions to constituent loads in stormflow during post-BMP conditions. Because there is substantial variability in constituent loads, regression analyses are used to remove some of the natural variability of the constituent loads and to improve the chances of detecting a statistically significant difference between pre- and post-BMP conditions.

The purpose of this section of the report is to evaluate preliminary regressions for pre-BMP conditions for the urban streams, and assess the likelihood for detecting changes in the individual watersheds. Four urban streams were included in this analysis, using constituent load data collected through water year 1996. This analysis was limited to suspended solids, total phosphorus, and total recoverable copper loads in stormflow.

Regression analyses require specification of a dependent variable and a set of independent variables thought to control the variability of the dependent variable. For this report, separate analyses were conducted with suspended solids, total phosphorus, and total recoverable copper chosen as dependent variables. Measures related to precipitation and time were chosen for independent variables, because these were felt to be free from any changes that may be induced through the installation of BMPs. Several primary precipitation measures were computed for individual storms: total rainfall, 15-and 30-minute maximum rainfall intensi- ties, and the Universal Soil Loss Equation (USLE) erosivity index (Wischmeier and Smith, 1978). Antecedent precipitation measures were computed as the total rainfall occurring 1-, 3-, 5- and 7-days prior to the beginning of each individual stormflow period.

Two periodic terms were computed to allow for the possibility of cyclical processes; the two terms were $\cos (2 \pi \mathrm{T} / 365.25)$ and $\sin (2 \pi \mathrm{T} / 365.25)$, where $\mathrm{T}$ is the beginning date of the storm, expressed as the number of years since 1904, and $\cos (\mathrm{x})$ and $\sin (\mathrm{x})$ are the trigonometric cosine and sine functions, respectively. Data was divided into three seasonal groups (spring, summer, fall). For the purposes of these analyses, spring was defined as March 1 through May 31, summer was defined as June 1 through August 31, and fall was defined as September 1 through December 15. A few winter storms were dropped from the analyses because there was not enough data to perform regressions for this period.

All possible regressions were computed for each of the four urban streams and the three dependent variables. Separate regression equations were determined for each group identified above. In some cases, the largest few constituent stormflow loads were dropped from the data set to allow for a more reasonable fit of the regression equation to the data. The constituent loads for the dropped storms were anomalously large, and could not be explained by any of the independent variables. One possible explanation is that there is a storage component to the sediment delivery process, and during some events the velocity in a stream may exceed a critical threshold and begin to scour the channel. Additional research is needed to define appropriate independent variables and bring the large loads back into the regressions. For Lincoln Creek, one storm was dropped due to insufficient rainfall data.

The resulting regressions are summarized for suspended solids, total phosphorus, and total recoverable copper in tables 6,7 and 8, respectively. For most regressions one or two independent variables were used; in some cases a third independent variable was used to increase the precision of the regression equation.

Two measures are used to report on the ability of the regression equation to explain the variability of the constituent loads. The traditional $\mathrm{R}^{2}$ value is reported, which is the portion of the total variability in the dependent variable that is "explained" by the regression. A second value, the standard error of the regression, is reported as a percentage of the mean value of the depen- 
Table 6. Summary of regression results for storm-runoff loads of suspended solids for urban streams

$\left[\mathrm{P}_{\mathrm{t}}\right.$, total precipitation; EI, Universal Soil Loss Equation Erosivity Index; $\mathrm{AP}_{\mathrm{j}}$, total precipitation for previous $\mathrm{i}$ day $(\mathrm{s}) ; \mathrm{I}_{\mathrm{n}}, \mathrm{n}$-minute maximum precipitation intensity; $\mathrm{T}$, starting date of stormflow period, in years since 1904; $\sin \left(\right.$ ), trigonometric sine function; $\cos \left(\right.$ ), trigonometric cosine function; $R^{2}$, fraction of variation explained by the regression]

\begin{tabular}{|c|c|c|c|c|}
\hline Group & Sample size & $\begin{array}{l}\text { Independent } \\
\text { variables }\end{array}$ & Adjusted $R^{2}$ & $\begin{array}{l}\text { Standard } \\
\text { error }^{1}\end{array}$ \\
\hline \multicolumn{5}{|c|}{ Nine Springs Creek Tributary } \\
\hline Spring & 16 & $P_{t}, \cos (2 \pi T), \sin (2 \pi T)$ & 0.7 & 44 \\
\hline Summer & 12 & $P_{t}, I_{15}$ & .87 & 30 \\
\hline Fall & 26 & $P_{t}, I_{15}, A_{1}$ & .87 & 39 \\
\hline \multicolumn{5}{|c|}{ Monroe Street Detention Pond Inlet } \\
\hline Spring & 14 & EI & .56 & 77 \\
\hline Summer & 20 & $\mathrm{I}_{15}, \mathrm{El}$ & .85 & 42 \\
\hline Fall & 8 & $P_{t}$ & .95 & 34 \\
\hline \multicolumn{5}{|c|}{ Menomonee River } \\
\hline Spring & 7 & EI & .98 & 24 \\
\hline Summer & 18 & $P_{t}$ & .59 & 83 \\
\hline Fall & 14 & $P_{t}$ & .69 & 37 \\
\hline \multicolumn{5}{|c|}{ Lincoln Creek } \\
\hline Spring & 8 & EI & .99 & 20 \\
\hline Summer & 26 & $\mathrm{I}_{15}, \mathrm{I}_{30}$ & .46 & 84 \\
\hline Fall & 9 & $P_{t}$ & .86 & 35 \\
\hline
\end{tabular}

${ }^{1}$ Standard ertor is expressed as a percent of the mean value of the independent variable.

dent variable. The standard error is essentially a measure of the variability of the regression residuals, which indicates the variability remaining in the dependent variable. Previous work by Walker (1994) has indicated that the standard error, expressed as a percent of the mean, can be used as a measure for the minimum change in before and after conditions that would be statistically significant. Experience from the preliminary results from the Black Earth Creek priority watershed (Walker and Graczyk, 1993) indicates that the minimum detectable change could be somewhat less than the pre$\mathrm{BMP}$ regression standard error.

The results for Lincoln Creek indicate that a change of 20-90 percent in suspended-solids stormflow load could be detected with a statistical test; the results for total phosphorus and total recoverable copper are less restrictive (25-50 percent). For the Menomonee River, a change in suspended solids, total phosphorus, and total recoverable copper load would have to be $20-80$ percent to be detected. For the Monroe Street detention pond inlet, a change in suspended-solids, total-phosphorus, and total recoverable copper load of 30-80 percent would be needed to be statistically significant. For
Nine Springs Creek Tributary, a change in suspendedsolids, and total-phosphorus load of $30-45$ percent would probably be detected with a statistical test but a change in total recoverable-copper stormflow load of $60-80$ percent would be needed to be statistically significant. For each of these sites, the reported figures for potential minimum detectable change should be considered in the context of the potential for BMPs in the individual watersheds to achieve the minimum levels of change.

For all of the sites, the figures reported for minimum detectable change could potentially decrease as the regression relations are explored further. More sophisticated statistical techniques could be used to divide the data into groups which behave similarly, and additional research may reveal better ways to incorporate the antecedent precipitation measures into the regressions. Conversely, the reported figures for minimum detectable change could potentially increase as the few storms with anomalously large loads are brought back into the regressions. 
Table 7. Summary of regression results for storm-runoff loads of total phosphorus for urban streams

$\left[\mathrm{P}_{\mathrm{t}}\right.$, total precipitation; EI, Universal Soil Loss Equation Erosivity Index; $\mathrm{AP}_{\mathrm{i}}$, tota] precipitation for previous day(s); $I_{n}$, n-minute maximum precipitation intensity; $T$, starting date of stormflow period, in years since 1904; $\sin ($ ), trigonometric sine function; $\cos ($ ). trigonometric cosine function; $R^{2}$, fraction of variation explained by the regression]

\begin{tabular}{|c|c|c|c|c|}
\hline Group & Sample size & $\begin{array}{l}\text { Independent } \\
\text { variabies }\end{array}$ & Adjusted $\mathrm{R}^{2}$ & $\begin{array}{l}\text { Standard } \\
\text { error }^{9}\end{array}$ \\
\hline \multicolumn{5}{|c|}{ Nine Springs Creek Tributary } \\
\hline Spring & 17 & $P_{t}, \cos (2 \pi T), \sin (2 \pi T)$ & 0.75 & 42 \\
\hline Surnmer & 13 & $\mathrm{I}_{15}, \mathrm{EI}$ & .86 & 43 \\
\hline Fall & 26 & $P_{t}, I_{15}, I_{30}$ & .87 & 38 \\
\hline \multicolumn{5}{|c|}{ Monroe Street Detention Pond inlet } \\
\hline Spring & 14 & EI & .36 & 57 \\
\hline Summer & 20 & EI & .86 & 32 \\
\hline Fall & 8 & $P_{\mathrm{t}}, \mathrm{EI}$ & .76 & 48 \\
\hline \multicolumn{5}{|c|}{ Menomonee River } \\
\hline Spring & 7 & EI & .95 & 32 \\
\hline Summer & 17 & $P_{t}, E I$ & .73 & 69 \\
\hline Fall & 14 & $\mathrm{P}_{1}, \mathrm{AP}_{5}$ & .71 & 44 \\
\hline \multicolumn{5}{|c|}{ Lincoin Creek } \\
\hline Spring & 8 & EI & .96 & 32 \\
\hline Summer & 26 & $\mathrm{P}_{\mathrm{t}}, \mathrm{I}_{15}, \mathrm{EI}$ & .6 & 51 \\
\hline Fall & 9 & $P_{t}$ & .67 & 44 \\
\hline
\end{tabular}

${ }^{1}$ Standard error is expressed as a percent of the mean value of the independent variable.

Table 8. Summary of regression results for storm-runoff loads of copper for urban streams

$\left[P_{t}\right.$, total precipitation; EI, Universal Soil Loss Equation Erosivity Index; $\mathbf{A P}_{\mathrm{p}}$, total precipitation for previous day(s); $I_{n}, n$-minute maximum precipitation intensity; $T$, starting date of stormflow period, in years since 1904; $\sin ($, trigonometric sine function; $\cos ()$, trigonometric cosine function; $R^{2}$, fraction of variation explained by the regression]

\begin{tabular}{|c|c|c|c|c|}
\hline Group & Sample size & $\begin{array}{l}\text { Independent } \\
\text { variables }\end{array}$ & Adjusted $\mathrm{R}^{2}$ & $\begin{array}{l}\text { Standerd } \\
\text { error }^{r}\end{array}$ \\
\hline \multicolumn{5}{|c|}{ Nine Springs Creek Trlbutary } \\
\hline Spring & 13 & $\mathrm{P}_{\mathrm{b}}, \mathrm{AP}_{7}$ & 0.72 & 60 \\
\hline Summer & 13 & I30, EI, $\mathrm{AP}_{7}$ & .95 & 87 \\
\hline Fall & 24 & $P_{t}, \cos (2 \pi T), \sin (2 \pi T)$ & .49 & 66 \\
\hline \multicolumn{5}{|c|}{ Monroe Street Detention Pond inlet } \\
\hline Spring & 11 & $\mathbf{P}_{\mathbf{t}}$ & .46 & 66 \\
\hline Summer & 14 & $\mathrm{I}_{30}, \mathrm{AP}_{3}$ & .76 & 31 \\
\hline Fall & 9 & $P_{t}$ & .9 & 36 \\
\hline \multicolumn{5}{|c|}{ Menomonee River } \\
\hline Spring & 7 & $P_{t}$ & .96 & 29 \\
\hline Summer & 14 & $P_{t}$ & .63 & 68 \\
\hline Fall & 13 & $\mathrm{P}_{\mathrm{t}}, \mathrm{AP}_{5}$ & .72 & 37 \\
\hline \multicolumn{5}{|c|}{ Lincoln Creek } \\
\hline Spring & 8 & EI & .95 & 29 \\
\hline Summer & 26 & $P_{t}, I_{15}$ & .64 & 48 \\
\hline Fall & 9 & $P_{t}$ & .88 & 25 \\
\hline
\end{tabular}

${ }^{1}$ Standard error is expressed as a percent of the mean value of the independent variable. 


\section{ANALYSIS OF LOAD TRENDS AT RURAL STREAM SITES}

For the eight rural streams, two have sufficient post-BMP storms for a final analysis, four have sufficient transitional storms for a preliminary analysis, and two have minimal BMP implementation that does not warrant further consideration. The final analysis will be reported elsewhere for the two streams with sufficient post-BMP storms (Brewery and Garfoot Creeks). The four streams with sufficient transitional data (Bower, Otter, Eagle, and Joos Valley Creeks) will be examined in this section. The remaining two streams (Rattlesnake and Kuenster Creeks) will not be examined due to minimal BMP implementation.

For Otter, Eagle, and Joos Valley Creeks, the storm-load data was divided into two periods: pre-BMP and transitional. The transitional period represents the time after the beginning of BMP installation and before completion of all planned BMPs. For Bower Creek, there were a sufficient number of transitional storms to allow for two transitional periods, labeled transitional-1 and transitional-2. The data was split into two periods sequentially to give an equal number of storms in the pre-BMP and transitional-2 periods. For this report, constituent-load data for suspended solids and total phosphorus were examined.

As discussed previously, a regression analysis can be used to help reduce the natural variability in the storm-load data (Walker and Graczyk, 1993; Walker, 1994). The overall set of independent variables used in the pre-BMP analysis for urban loads (previous section) was used for the rural sites. As with the urban analysis, the data were further divided into one of three groups, corresponding to one of three seasons: spring, summer, or fall. These seasons correspond roughly to the different processes of runoff generation and the different condition of soil cover during the year. In addition, for one site (Joos Valley Creek) it was necessary to break the data down further into groups corresponding to the antecedent moisture condition (AMC) classes used by SCS (U.S. Soil Conservation Service, 1972). For Joos Valley Creek, AMC-I, which corresponds to relatively dry pre-storm conditions, was further divided into the three seasons. The second group, AMC-II, which corresponds to relatively wet pre-storm conditions, was considered to be a separate group.

The resulting regressions for suspended sediment and total phosphorus are summarized in tables 9 and 10, respectively. In all cases, the regression analysis for a particular group is fit to both pre-BMP and traditional data. The tables present the individual sample sizes for the groups, the independent variables used in the final regression, and two terms which measure the goodnessof-fit of the regressions. The adjusted $R^{2}$ is a measure of the portion of the variability in the dependent variable that is accounted for by the regression. The standard error term is the standard deviation of the regression residuals (the unexplained portion of the dependent variable) divided by the average value of the dependent variable. Dividing by the average value of the dependent variable scales the data and provides a more comparable measure between the regressions.

For a particular site, the residuals from each regression group were combined to give a data set of residuals across all regression groups. Because the regression residuals represent the variability not accounted for by the independent variables, the variability remaining is due to either the effect of the BMPs or another factor not considered in the list of independent variables. The regression residuals, along with the actual storm loads, were tested for statistical differences between the preBMP and transitional periods using a non-parametric test (Mann-Whitney U test). The Mann-Whitney U test is a procedure for determining if the data from one data set is larger than the data from the second data set. The procedure works better than equivalent parametric tests if the underlying data deviates from normality.

The results of the statistical tests applied to the raw constituent loads and regression residuals for suspended solids and total phosphorus are presented in tables 11 and 12 , respectively. Using a confidence level of 95 percent (there is a 5 percent chance that the conclusion that the data sets are different is wrong), the raw data reveal that there is no significant difference between the pre-BMP and transitional periods (significance levels are all greater than 0.05 ). For the regression residuals, most of the comparisons yield the same conclusion that there is no significant difference between the loads in the pre-BMP and transitional periods after accounting for natural variability. For Otter Creek, however, there appears to be a statistically-significant reduction in the suspended-solids loads (significance level of 0.035), and for Joos Valley Creek there appears to be a statistically-significant reduction in both the suspended-solids and total-phosphorus loads (significance levels of 0.012 and 0.004 , respectively). For Otter Creek, an explanation of why a statistically-significant reduction in suspended solids has been detected and total phosphorus has not requires a detailed examination 
Table 9. Summary of regression results for storm-runoff loads of suspended solids for rural streams

[P, total precipitation; EI, Universal Soil Loss Equation Erosivity Index; $\mathrm{AP}_{\mathrm{i}}$, total precipitation for previous i day(s); $\mathrm{I}_{\mathrm{n}}$, $\mathrm{n}$-minute maximum precipitation intensity; $\mathrm{T}$, starting date of stormflow period, in years since 1904; $\sin \left(\right.$ ), trigonometric sine function; $\cos \left(\right.$ ), trigonometric cosine function; $\mathrm{R}^{2}$, fraction of variation explained by the regression]

\begin{tabular}{|c|c|c|c|c|}
\hline Group & Sample size & $\begin{array}{l}\text { Independent } \\
\text { variables }\end{array}$ & Adjusted $\mathrm{R}^{2}$ & Standard error ${ }^{1}$ \\
\hline \multicolumn{5}{|c|}{ Bower Creek } \\
\hline Spring & 14 & EI & 0.89 & 72 \\
\hline Summer & 18 & $\mathrm{P}_{\mathrm{I}}, \mathrm{AP}_{\mathrm{l}}$ & .54 & 140 \\
\hline Fall & 16 & $P_{8}+A P_{1}, E I$ & .80 & 93 \\
\hline \multicolumn{5}{|c|}{ Otter Creek } \\
\hline Spring & 14 & $A P_{1}, P_{t}+A P_{5}$ & .84 & 60 \\
\hline Summer & 17 & EI & .66 & 100 \\
\hline Fall & 15 & $\cos (2 \pi T)$ & .61 & 83 \\
\hline \multicolumn{5}{|c|}{ Eagle Creek } \\
\hline Spring & 14 & EI & .76 & 96 \\
\hline Summer & 25 & $\mathrm{EI}, \mathrm{AP}_{3}$ & .93 & 56 \\
\hline Fall & 5 & $P_{t}+A P_{1}$ & .92 & 45 \\
\hline \multicolumn{5}{|c|}{ Joos Valley Creek } \\
\hline AMC I, Spring & 8 & $P_{t}$ & .56 & 110 \\
\hline AMC I, Summer & 22 & $\mathrm{EI}, \mathrm{I}_{30}$ & .71 & 120 \\
\hline AMC I, Fall & 4 & EI & .99 & 16 \\
\hline AMC II & 12 & EI & .98 & 34 \\
\hline
\end{tabular}

'Standard error is expressed as a percent of the mean value of the independent variable.

Table 10. Summary of regression results for storm-runoff loads of total phosphorus for rural streams

$\mathrm{P}_{\mathrm{l}}$, total precipitation; EI, Universal Soil Loss Equation Erosivity Index; $\mathrm{AP}_{\mathrm{i}}$, total precipitation for previous i day(s); $I_{n}$, n-minute maximum precipitation intensity; T, starting date of stormflow period, in years since 1904; $\sin \left(\right.$ ), trigonometric sine function; $\cos \left(\right.$ ), trigonometric cosine function; $\mathbf{R}^{2}$, fraction of variation explained by the regression]

\begin{tabular}{|c|c|c|c|c|}
\hline Group & Sample slze & $\begin{array}{l}\text { Independent } \\
\text { variables }\end{array}$ & Adjusted $R^{2}$ & Standard error ${ }^{1}$ \\
\hline \multicolumn{5}{|c|}{ Bower Creek } \\
\hline Spring & 14 & EI & 0.72 & 82 \\
\hline Summer & 17 & $P_{t}, A P_{1}, P_{t}$ & .46 & 130 \\
\hline Fall & 16 & $\mathrm{P}_{\mathrm{t}}+\mathrm{AP}_{1}, \mathrm{EI}$ & .79 & 79 \\
\hline \multicolumn{5}{|c|}{ Otter Creek } \\
\hline Spring & 14 & $P_{t}+A P_{5}, A P_{1}$ & .84 & 58 \\
\hline Summer & 17 & EI & .69 & 82 \\
\hline Fall & 15 & $\cos (2 \pi T)$ & .51 & 62 \\
\hline \multicolumn{5}{|c|}{ Eagle Creek } \\
\hline Spring & 14 & $P_{t}+A P_{1}$ & .54 & 94 \\
\hline Summer & 25 & El, $\mathrm{AP}_{3}$ & .93 & 54 \\
\hline Fall & 5 & $P_{t}$ & .90 & 47 \\
\hline \multicolumn{5}{|c|}{ Joos Valley Creek } \\
\hline AMC I, Spring & 8 & $P_{1}$ & .59 & 100 \\
\hline AMC 1, Summer & 22 & $\mathrm{EI}, \mathrm{I}_{30}$ & .78 & 88 \\
\hline AMC I, Fall & 4 & EI & .99 & 15 \\
\hline AMC II & 12 & EI & .98 & 32 \\
\hline
\end{tabular}

${ }^{1}$ Standard error is expressed as a percent of the mean value of the independent variable. 
Table 11. Results of Mann-Whitney $U$ test comparing suspended solids storm loads from pre-BMP to transitional periods

[BMP, Best-Management Practice; pre-BMP, period before installation of BMPs; Transitional-1, first period after start of BMP installation: Transitional-2, period succeeding Transitional-1]

\begin{tabular}{|c|c|c|c|c|c|}
\hline \multicolumn{2}{|c|}{ Group 1} & \multicolumn{2}{|c|}{ Group 2} & \multicolumn{2}{|c|}{ Significance level } \\
\hline Period & Sample size & Period & Sample size & Raw data & Residuals \\
\hline \multicolumn{6}{|c|}{ Bower Creek } \\
\hline Pre-BMP & 18 & Transitional-1 & 11 & 0.611 & 0.672 \\
\hline Pre-BMP & 18 & Transitional-2 & 18 & .924 & .752 \\
\hline \multicolumn{6}{|c|}{ Otter Creek } \\
\hline Pre-BMP & 29 & Transitional-1 & 16 & .286 & .035 \\
\hline \multicolumn{6}{|c|}{ Eagle Creek } \\
\hline Pre-BMP & 28 & Transitional-1 & 16 & .113 & .542 \\
\hline \multicolumn{6}{|c|}{ Joos Valley Creek } \\
\hline Pre-BMP & 21 & Transitional-1 & 25 & .229 & .012 \\
\hline
\end{tabular}

Table 12. Results of Mann-Whitney $U$ test comparing total phosphorus storm loads from pre-BMP to transitional periods

[BMP, Best-Management Practice; pre-BMP, period before installation of BMPs; Transitional-1, first period after start of BMP installation; Transitional-2, period succeeding Transitional-1]

\begin{tabular}{|c|c|c|c|c|c|}
\hline \multicolumn{2}{|c|}{ Group 1} & \multicolumn{2}{|c|}{ Group 2} & \multicolumn{2}{|c|}{ SIgnificance level } \\
\hline Period & Sample slze & Period & Sample size & Raw data & Residuals \\
\hline \multicolumn{6}{|c|}{ Bower Creek } \\
\hline Pre-BMP & 18 & Transitional-1 & 11 & 0.589 & 0.653 \\
\hline Pre-BMP & 18 & Transitional-2 & 18 & .825 & .327 \\
\hline \multicolumn{6}{|c|}{ Otter Creek } \\
\hline Pre-BMP & 29 & Transitional-1 & 16 & .538 & .981 \\
\hline \multicolumn{6}{|c|}{ Eagle Creek } \\
\hline Pre-BMP & 28 & Transitional-1 & 16 & .092 & .903 \\
\hline \multicolumn{6}{|c|}{ Joos Valley Creek } \\
\hline Pre-BMP & 21 & Transitional-1 & 25 & .146 & .004 \\
\hline
\end{tabular}

of the BMPs installed. For the streams and constituents without significant differences, one of two possibilities exist: (1) either the BMP installation to date has not reduced the loads of the constituent in question, or (2) the BMP installation to date has reduced the loads, but the variability remaining in the residuals is masking the change. It is possible that completion of the BMP installations and collection of post-BMP loads after the practices have had enough time to begin working will result in more statistically-significant decreases in the constituent loads.

\section{CONCLUSIONS}

For the five rural streams with continuous dissolved-oxygen monitoring, there have been some improvements in the dissolved-oxygen concentrations.
The results, however, are not consistent from year to year. Thus it is not possible to attribute the changes in dissolved oxygen concentration to the implementation of BMPs.

For the four urban stream sites, an evaluation of regressions for pre-BMP loads resulted in a wide range of minimum detectable changes that likely could be detected after BMP implementation. For three of the sites, the minimum detectable change ranges from 20 90 percent for the three constituents considered. It is likely that the expected change from BMPs would be less than these values, hence could not be detected statistically. For one site (Nine Springs Creek Tributary) the minimum statistically detectable change for suspended solids and total phosphorus ranged from 30 45 percent, which is well within the range expected for urban BMPs. Thus for this site it is possible that post- 
BMP changes would be detected using statistical techniques.

For the eight rural streams sites, two sites had sufficient post-BMP data for analysis and the results will be reported elsewhere. Of the remaining six rural streams, four had sufficient transitional data to warrant a preliminary analysis. For all of the streams, the BMPs implemented during the transitional period have not significantly reduced the actual storm loads for suspended solids and phosphorus. Multiple regressions were used to remove some of the natural variability in the data. Based on the residual analysis, for Otter Creek there appears to be a significant reduction in suspended-solids load, and for Joos Valley Creek there appears to be a significant reduction in the suspended-solids and totalphosphorus loads after accounting for natural variability. It is possible that the other sites will also show statistically significant reductions in suspended solids and total phosphorus if additional BMPs are implemented.

\section{REFERENCES CITED}

Dong, Allen, Chesters, Gordon, and Simsiman, G.V., 1979, Dispersibility of soils and elemental composition of soils, sediments, and dust and dirt from the Menomonee River Watershed: U.S. Environmental Protection Agency Report EPS-905/4-79-029-F, 56 p.

Holmstrom, B.K., Kammerer, P.A., Jr., and Erickson, R.M., 1986, Water resources data, Wisconsin, water year 1985: U.S. Geological Survey Water-Data Report WI-85-1, $414 \mathrm{p}$.

1987, Water resources data, Wisconsin, water year 1986: U.S. Geological Survey Water-Data Report WI-86-1, $402 \mathrm{p}$.

1989, Water resources data, Wisconsin, water year 1989: U.S. Geological Survey Water-Data Report WI-89-1, $436 \mathrm{p}$.

1990, Water resources data, Wisconsin, water year 1990: U.S. Geological Survey Water-Data Report WI-90-1, $578 \mathrm{p}$.

1991, Water resources data, Wisconsin, water year 1991: U.S. Geological Survey Water-Data Report WI-91-1, $607 \mathrm{p}$.

Holmstrom, B.K., Kammerer, P.A., Jr., and Ellefson, B.R., 1992, Water resources data, Wisconsin, water year 1992: U.S. Geological Survey Water-Data Report WI-92-1, $545 \mathrm{p}$.

1993, Water resources data, Wisconsin, water year 1993: U.S. Geological Survey Water-Data Report WI-93-1, $707 \mathrm{p}$.
1994, Water resources data, Wisconsin, water year 1994: U.S. Geological Survey Water-Data Report WI-94-1, $645 \mathrm{p}$.

Holmstrom, B.K., Olson, D.L., and Ellefson, B.R., 1995, Water resources data, Wisconsin, water year 1995: U.S. Geological Survey Water-Data Report WI-95-1, 562 p.

1996, Water resources data, Wisconsin, water year 1996: U.S. Geological Survey Water-Data Report WI-96-1, $464 \mathrm{p}$.

1997, Water resources data, Wisconsin, water year 1997: U.S. Geological Survey Water-Data Report WI-97-1, $506 \mathrm{p}$.

1998, Water resources data, Wisconsin, water year 1998: U.S. Geological Survey Water-Data Report WI-98-1, $508 \mathrm{p}$.

Rappold, K.F., Wierl, J.A., and Amerson, F.U., 1997, Watershed characteristics and land management in the nonpoint-source evaluation monitoring watershed in Wisconsin: U.S. Geological Survey Open-File Report 97-119, $39 \mathrm{p}$.

U.S. Soil Conservation Service, 1972, SCS national engineering handbook, Section 4-Hydrology: U.S. Department of Agriculture [variously paginated].

Walker, J.F., 1994, Statistical techniques for assessing waterquality effects of BMPs: ASCE Journal of Irrigation and Drainage Engineering, v. 120, no. 2, p. 334-347.

Walker, J.F., and Graczyk, D.J., 1993, Preliminary evaluation of effects of Best Management Practices in the Black Earth Creek, Wisconsin, Priority Watershed:, Water Science and Technology v. 28, no. 3-5, p. 539-548.

Wierl, J.A., Rappold, K.F., and Amerson, F.U., 1996, Summary of the landuse inventory for the nonpoint-source evaluation monitoring watershed in Wisconsin: U.S. Geological Survey Open-File Report 96-123, 23 p.

Wierl, J.A., Giddings, E.P.M., and Bannerman, R.T., 1998, Evaluation of method for comparing phosphorus loads from barnyards and croplands in Otter Creek watershed, Wisconsin: U.S. Geological Survey Fact Sheet FS-168$984 \mathrm{p}$.

Wischmeier, W.H., and D.D. Smith, 1978, Predicting rainfall erosion losses - a guide to conservation planning: U.S. Department of Agriculture, Agriculture Handbook No. 537, Washington, D.C., 58 p.

Wisconsin Administrative Code, 1992, Rules of Department of Natural Resources environmental protection: Wisconsin Administrative Code S.NR.100.01. 


\section{APPENDIX}


Appendix. Storm-load data for rural watershed-management evaluation monitoring sites, Wisconsin, water years ${ }^{1}$ 1985-98

[yr, year; mo, month; d, day; h, hour; in., inches; Mft ${ }^{3}$, million cubic feet; tb, pounds; s/m, snowmelt; --, no data]

\begin{tabular}{|c|c|c|c|c|c|c|c|}
\hline \multicolumn{2}{|c|}{ Start of storm } & \multicolumn{2}{|c|}{ End of storm } & \multirow[b]{2}{*}{$\begin{array}{l}\text { Precipitation } \\
\text { (in.) }\end{array}$} & \multirow[b]{2}{*}{$\begin{array}{c}\text { Streamflow } \\
\text { volume } \\
\left(\mathrm{Mft}^{3}\right)\end{array}$} & \multicolumn{2}{|c|}{ Loads } \\
\hline $\begin{array}{c}\text { Date } \\
\text { (yr/mo/d) }\end{array}$ & $\begin{array}{l}\text { Time } \\
(24 \mathrm{~h})\end{array}$ & $\begin{array}{c}\text { Date } \\
\text { (yr/mo/d) }\end{array}$ & $\begin{array}{l}\text { Time } \\
(24 \mathrm{~h})\end{array}$ & & & $\begin{array}{l}\text { Suspended- } \\
\text { solids load } \\
\text { (tons) }\end{array}$ & $\begin{array}{c}\text { Total- } \\
\text { phosphorus } \\
\text { load } \\
\text { (lb) }\end{array}$ \\
\hline \multicolumn{8}{|c|}{ Brewery Creek } \\
\hline $84 / 10 / 18$ & 1745 & $84 / 10 / 19$ & 1700 & 2.78 & 1.5 & 35 & 140 \\
\hline $84 / 11 / 01$ & 0015 & $84 / 11 / 01$ & 2245 & .93 & .48 & 7.4 & 28 \\
\hline $84 / 12 / 28$ & 0045 & $84 / 12 / 28$ & 2145 & $\mathrm{~s} / \mathrm{m}$ & 1.3 & 22 & 180 \\
\hline $85 / 02 / 21$ & 0430 & $85 / 02 / 25$ & 0700 & $\mathrm{~s} / \mathrm{m}$ & 9.6 & 120 & 1,500 \\
\hline $85 / 07 / 24$ & 1930 & $85 / 07 / 26$ & 2230 & 6.85 & 14 & 500 & 2,000 \\
\hline $85 / 08 / 12$ & 2145 & $85 / 08 / 13$ & 1800 & .94 & .25 & 1.2 & 13 \\
\hline $85 / 08 / 25$ & 0200 & $85 / 08 / 26$ & 1000 & 1.70 & .53 & 2.6 & - \\
\hline $85 / 09 / 04$ & 2330 & $85 / 09 / 05$ & 2115 & 1.53 & .56 & 2.3 & 38 \\
\hline $85 / 09 / 09$ & 0015 & $85 / 09 / 09$ & 2345 & 1.40 & 1.3 & 25 & 130 \\
\hline $85 / 10 / 12$ & 0315 & $85 / 10 / 13$ & 0200 & .80 & .76 & 3.3 & - \\
\hline $85 / 10 / 23$ & 1515 & $85 / 10 / 24$ & 1400 & .59 & .39 & 2.3 & 20 \\
\hline $85 / 10 / 31$ & 1800 & $85 / 11 / 02$ & 1100 & 2.77 & 2.4 & 20 & 190 \\
\hline $85 / 11 / 17$ & 2245 & $85 / 11 / 19$ & 0800 & .63 & .85 & 3.5 & 55 \\
\hline $86 / 03 / 09$ & 2200 & $86 / 03 / 10$ & 2300 & $\mathrm{~s} / \mathrm{m}$ & .67 & 8.1 & -- \\
\hline $86 / 03 / 17$ & 1200 & $86 / 03 / 20$ & 0100 & $\mathrm{~s} / \mathrm{m}$ & 3.1 & 60 & 330 \\
\hline $86 / 05 / 15$ & 1500 & $86 / 05 / 16$ & 0200 & .58 & .28 & 1.2 & 18 \\
\hline $86 / 05 / 17$ & 0100 & $86 / 05 / 18$ & 0600 & 1.09 & .96 & 8.1 & 78 \\
\hline $86 / 06 / 22$ & 0100 & $86 / 06 / 22$ & 2300 & 1.16 & .77 & 1.1 & 24 \\
\hline $89 / 10 / 05$ & 0745 & $89 / 10 / 05$ & 1500 & -- & .020 & .040 & 1.1 \\
\hline $90 / 03 / 08$ & 0930 & $90 / 03 / 09$ & 0500 & .67 & 1.8 & 590 & 750 \\
\hline $90 / 03 / 11$ & 0600 & $90 / 03 / 12$ & 0200 & .50 & 2.5 & 160 & 820 \\
\hline $90 / 03 / 13$ & 1815 & $90 / 03 / 14$ & 0600 & .84 & .89 & 48 & 250 \\
\hline $90 / 06 / 02$ & 1315 & $90 / 06 / 03$ & 1000 & 1.54 & .59 & 35 & 140 \\
\hline $90 / 06 / 28$ & 2330 & $90 / 06 / 29$ & 1900 & 2.14 & 4.1 & 250 & 1,100 \\
\hline $91 / 04 / 12$ & 1230 & $91 / 04 / 13$ & 1230 & 1.17 & .75 & 8.3 & 85 \\
\hline $91 / 04 / 14$ & 0600 & $91 / 04 / 14$ & 2400 & .80 & .61 & 4.1 & 54 \\
\hline $91 / 04 / 28$ & 2045 & $91 / 04 / 29$ & 1100 & 1.24 & .29 & 7.1 & 47 \\
\hline $91 / 05 / 05$ & 0900 & $91 / 05 / 05$ & 2400 & 1.08 & .24 & 3.4 & 25 \\
\hline $91 / 07 / 01$ & 1415 & $91 / 07 / 02$ & 1500 & 1.29 & .34 & 1.7 & 27 \\
\hline $91 / 07 / 07$ & 1430 & $91 / 07 / 08$ & 1315 & 1.11 & .52 & 3.1 & 56 \\
\hline $91 / 08 / 08$ & 0130 & $91 / 08 / 08$ & 0900 & 2.24 & .14 & .97 & 9.9 \\
\hline $91 / 10 / 24$ & 2000 & $91 / 10 / 26$ & 0100 & 3.55 & 2.9 & 120 & 740 \\
\hline $91 / 11 / 01$ & 0030 & $91 / 11 / 02$ & 1330 & .81 & .88 & 5.4 & 90 \\
\hline $91 / 11 / 29$ & 1900 & $91 / 11 / 30$ & 1800 & .61 & .44 & 2.3 & 32 \\
\hline $92 / 02 / 27$ & 1030 & $92 / 02 / 28$ & 0500 & $\mathrm{~s} / \mathrm{m}$ & .87 & 6.7 & 130 \\
\hline $92 / 02 / 28$ & 0845 & $92 / 02 / 29$ & 0300 & $\mathrm{~s} / \mathrm{m}$ & .98 & 14 & 160 \\
\hline $92 / 03 / 01$ & 1200 & $92 / 03 / 02$ & 0700 & $\mathrm{~s} / \mathrm{m}$ & .66 & 20 & 120 \\
\hline
\end{tabular}


Appendix. Storm-load data for rural watershed-management evaluation monitoring sites, Wisconsin, water years ${ }^{1}$ 1985-98-Continued

[yt, year; mo, month; d, day; $h$, hour; in., inches; $\mathrm{Mft}^{3}$, million cubic feet; lb, pounds; s/m, snowmelt; --, no data]

\begin{tabular}{|c|c|c|c|c|c|c|c|}
\hline \multicolumn{2}{|c|}{ Start of storm } & \multicolumn{2}{|c|}{ End of storm } & \multirow[b]{2}{*}{$\begin{array}{l}\text { Precipitation } \\
\text { (ln.) }\end{array}$} & \multirow[b]{2}{*}{$\begin{array}{c}\text { Streamflow } \\
\text { voiume } \\
\left(\mathrm{Mft}^{3}\right)\end{array}$} & \multicolumn{2}{|c|}{ Loads } \\
\hline $\begin{array}{c}\text { Date } \\
\text { (yr/mo/d) }\end{array}$ & $\begin{array}{l}\text { Time } \\
(24 \mathrm{~h})\end{array}$ & $\begin{array}{c}\text { Data } \\
(\mathrm{yr} / \mathrm{mo} / \mathrm{d})\end{array}$ & $\begin{array}{l}\text { Time } \\
(24 h)\end{array}$ & & & $\begin{array}{l}\text { Suspendad- } \\
\text { soiids ioad } \\
\text { (tons) }\end{array}$ & $\begin{array}{c}\text { Total- } \\
\text { phosphorus } \\
\text { load } \\
\text { (lb) }\end{array}$ \\
\hline \multicolumn{8}{|c|}{ Brewery Creek-Continued } \\
\hline $92 / 07 / 13$ & 1500 & $92 / 07 / 15$ & 0300 & 1.49 & .34 & - & 36 \\
\hline $92 / 08 / 29$ & 0330 & $92 / 08 / 29$ & 1100 & 1.21 & .037 & .13 & .78 \\
\hline $92 / 09 / 16$ & 1100 & $92 / 09 / 17$ & 1800 & 1.19 & .25 & .51 & 27 \\
\hline $92 / 09 / 18$ & 0330 & $92 / 09 / 19$ & 1700 & .73 & .33 & .47 & 18 \\
\hline $92 / 10 / 15$ & 1800 & $92 / 10 / 15$ & 2300 & .45 & .019 & .020 & .28 \\
\hline $92 / 11 / 20$ & 0300 & $92 / 11 / 22$ & 0600 & 2.55 & 1.4 & 7.5 & 100 \\
\hline $93 / 03 / 06$ & 1000 & $93 / 03 / 07$ & 0815 & $\mathrm{~s} / \mathrm{m}$ & .60 & 13 & 440 \\
\hline $93 / 03 / 07$ & 1200 & $93 / 03 / 08$ & 0800 & $\mathrm{~s} / \mathrm{m}$ & 1.2 & 9.3 & 490 \\
\hline $93 / 03 / 08$ & 1300 & $93 / 03 / 09$ & 0400 & $\mathrm{~s} / \mathrm{m}$ & .83 & 7.8 & 380 \\
\hline $93 / 03 / 16$ & 0700 & $93 / 03 / 17$ & 0800 & $\mathrm{~s} / \mathrm{m}$ & 1.7 & 73 & 640 \\
\hline $93 / 03 / 24$ & 1000 & $93 / 03 / 25$ & 0700 & $\mathrm{~s} / \mathrm{m}$ & 2.1 & 36 & 330 \\
\hline $93 / 03 / 25$ & 1000 & $93 / 03 / 26$ & 0800 & $\mathrm{~s} / \mathrm{m}$ & 2.3 & 67 & 460 \\
\hline $93 / 03 / 26$ & 1200 & $93 / 03 / 27$ & 0800 & $\mathrm{~s} / \mathrm{m}$ & 2.3 & -- & 160 \\
\hline $93 / 03 / 27$ & 1200 & $93 / 03 / 28$ & 0800 & $\mathrm{~s} / \mathrm{m}$ & 1.2 & 16 & 98 \\
\hline $93 / 03 / 28$ & 1100 & $93 / 03 / 29$ & 0700 & $\mathrm{~s} / \mathrm{m}$ & 2.9 & 210 & 590 \\
\hline $93 / 03 / 31$ & 0300 & $93 / 04 / 01$ & 0300 & $\mathrm{~s} / \mathrm{m}$ & 2.5 & 55 & 250 \\
\hline $93 / 06 / 07$ & 1035 & $93 / 06 / 08$ & 1000 & 2.39 & 2.5 & 110 & 470 \\
\hline $93 / 06 / 17$ & 1000 & $93 / 06 / 18$ & 1200 & .43 & .93 & 18 & 67 \\
\hline $93 / 07 / 05$ & 0430 & $93 / 07 / 07$ & 0900 & 4.58 & 16 & 1,300 & 4,000 \\
\hline $93 / 07 / 07$ & 1800 & $93 / 07 / 08$ & 0900 & 1.03 & 1.3 & 130 & 460 \\
\hline $93 / 07 / 09$ & 0100 & $93 / 07 / 10$ & 0400 & 1.47 & 5.1 & 250 & 570 \\
\hline $93 / 07 / 17$ & 1100 & $93 / 07 / 18$ & 0400 & .86 & .84 & 42 & 87 \\
\hline $93 / 07 / 25$ & 0100 & $93 / 07 / 26$ & 0400 & 1.35 & 2.1 & 83 & 300 \\
\hline $93 / 07 / 27$ & 2200 & $93 / 07 / 28$ & 1900 & .88 & 1.4 & 25.8 & 120 \\
\hline $93 / 08 / 15$ & 0500 & $93 / 08 / 16$ & 2000 & 2.48 & 4.7 & 88.6 & 470 \\
\hline $93 / 09 / 13$ & 0800 & $93 / 09 / 15$ & 1500 & 2.12 & 2.9 & 12.1 & 130 \\
\hline $94 / 02 / 18$ & 1300 & $94 / 02 / 21$ & 1200 & - & 4.9 & 220 & 780 \\
\hline $94 / 03 / 05$ & 1100 & $94 / 03 / 06$ & 0800 & -- & 2.8 & 72 & 510 \\
\hline $94 / 03 / 06$ & 0900 & $94 / 03 / 07$ & 0700 & -- & 1.7 & 30 & 110 \\
\hline $94 / 06 / 23$ & 1230 & $94 / 06 / 24$ & 2100 & -- & 1.2 & 4.2 & 62 \\
\hline $94 / 06 / 25$ & 2100 & $94 / 06 / 27$ & 0100 & -- & .66 & 2.1 & 16 \\
\hline $94 / 07 / 03$ & 2345 & $94 / 07 / 05$ & 2300 & - & 5.9 & 200 & 930 \\
\hline $94 / 08 / 10$ & 1530 & $94 / 08 / 12$ & 0200 & -- & 1.1 & 2.5 & 32 \\
\hline $94 / 09 / 14$ & 0400 & $94 / 09 / 15$ & 0500 & -- & .65 & 4.1 & 36 \\
\hline $94 / 11 / 27$ & 1215 & $94 / 11 / 28$ & 1815 & 1.15 & 9.8 & 13 & 57 \\
\hline $95 / 03 / 11$ & 0900 & $95 / 03 / 12$ & 0900 & $\mathrm{~s} / \mathrm{m}$ & 19 & 130 & 450 \\
\hline $95 / 05 / 09$ & 1900 & $95 / 05 / 11$ & 0015 & .85 & 6 & 1.4 & 19 \\
\hline
\end{tabular}


Appendix. Storm-load data for rural watershed-management evaluation monitoring sites, Wisconsin, water years ${ }^{1}$ 1985-98-Continued

[yr, year; mo, month; d, day; h, hour: in., inches; $\mathrm{Mft}^{3}$, million cubic feet; lb, pounds; s/m, snowmelt; --, no data]

\begin{tabular}{|c|c|c|c|c|c|c|c|}
\hline \multicolumn{2}{|c|}{ Start of storm } & \multicolumn{2}{|c|}{ End of storm } & \multirow[b]{2}{*}{$\begin{array}{l}\text { Preclpitation } \\
\text { (in.) }\end{array}$} & \multirow[b]{2}{*}{$\begin{array}{c}\text { Streamfiow } \\
\text { volume } \\
\left(\mathrm{Mft}^{3}\right)\end{array}$} & \multicolumn{2}{|c|}{ Loads } \\
\hline $\begin{array}{c}\text { Date } \\
\text { (yr/mo/d) }\end{array}$ & $\begin{array}{l}\text { Time } \\
(24 \mathrm{~h})\end{array}$ & $\begin{array}{c}\text { Date } \\
\text { (yr/mo/d) }\end{array}$ & $\begin{array}{l}\text { Time } \\
(24 \mathrm{~h})\end{array}$ & & & $\begin{array}{l}\text { Suspended- } \\
\text { solids load } \\
\text { (tons) }\end{array}$ & $\begin{array}{l}\text { Total- } \\
\text { phosphorus } \\
\text { load } \\
\text { (ib) }\end{array}$ \\
\hline \multicolumn{8}{|c|}{ Brewery Creek - Continued } \\
\hline $95 / 10 / 05$ & 1800 & $95 / 10 / 08$ & 0200 & 1.82 & 8.6 & 4.3 & 41 \\
\hline $95 / 11 / 01$ & 0945 & $95 / 11 / 03$ & 1600 & 1.49 & 15. & 6.2 & 54 \\
\hline $96 / 01 / 17$ & 2300 & $96 / 01 / 22$ & 2000 & .87 & 31 & 92 & 410 \\
\hline $96 / 02 / 09$ & 1500 & $96 / 02 / 12$ & 0100 & $\mathrm{~s} / \mathrm{m}$ & 33 & 14 & 360 \\
\hline $96 / 02 / 26$ & 1500 & $96 / 02 / 27$ & 2300 & $\mathrm{~s} / \mathrm{m}$ & 38 & 160 & 720 \\
\hline $96 / 05 / 09$ & 2100 & $96 / 05 / 11$ & 2000 & 1.94 & 27 & 320 & 1,100 \\
\hline $96 / 06 / 01$ & 1500 & $96 / 06 / 02$ & 2000 & 1.13 & 4.6 & 2.5 & 14 \\
\hline $96 / 06 / 05$ & 2100 & $96 / 06 / 08$ & 1600 & 1.37 & 11 & 3 & 36 \\
\hline $96 / 06 / 16$ & 2245 & $96 / 06 / 20$ & 0400 & 4.55 & 80 & 200 & 960 \\
\hline $96 / 07 / 17$ & 2200 & $96 / 07 / 20$ & 0500 & 2.64 & 33 & 47 & 290 \\
\hline $96 / 08 / 05$ & 1600 & $96 / 08 / 08$ & 0400 & 1.89 & 12 & 2 & 34 \\
\hline $96 / 10 / 29$ & 0930 & $96 / 10 / 30$ & 1500 & 1.29 & 5.8 & 3.6 & 12 \\
\hline $97 / 01 / 04$ & 0300 & $96 / 01 / 05$ & 1145 & .55 & 20 & 66 & 300 \\
\hline $97 / 01 / 21$ & 2200 & $97 / 01 / 23$ & 0800 & $\mathrm{~s} / \mathrm{m}$ & 26 & 29 & 240 \\
\hline $97 / 02 / 18$ & 1000 & $97 / 02 / 19$ & 0900 & $\mathrm{~s} / \mathrm{m}$ & 53 & 170 & 900 \\
\hline $97 / 02 / 20$ & 1400 & $97 / 02 / 22$ & 0300 & 1.00 & 39 & 150 & 770 \\
\hline $97 / 02 / 28$ & 1400 & $97 / 03 / 02$ & 0700 & $\mathrm{~s} / \mathrm{m}$ & 37 & 140 & 560 \\
\hline $97 / 03 / 09$ & 0500 & $97 / 03 / 10$ & 0700 & .49 & 18 & 84 & 300 \\
\hline $97 / 04 / 30$ & 1600 & $97 / 05 / 01$ & 2100 & 1.38 & 6.1 & 3.3 & 21 \\
\hline $97 / 06 / 15$ & 1100 & $97 / 06 / 16$ & 1800 & 1.88 & 4.8 & 4 & 32 \\
\hline $97 / 06 / 21$ & 0400 & $97 / 06 / 21$ & 2400 & 1.69 & 7.2 & 8.1 & 55 \\
\hline $97 / 07 / 08$ & 0200 & $97 / 07 / 09$ & 0300 & 1.29 & 5.8 & 1.9 & 22 \\
\hline $97 / 07 / 20$ & 2300 & $97 / 07 / 22$ & 0200 & 1.60 & 7 & 5.7 & 58 \\
\hline $98 / 02 / 15$ & 1200 & $98 / 02 / 17$ & 1900 & .23 & 6.5 & 3.6 & 13 \\
\hline $98 / 03 / 30$ & 1200 & $98 / 04 / 02$ & 1200 & 3.99 & 58 & 270 & 1,200 \\
\hline $98 / 05 / 07$ & 1000 & $98 / 05 / 09$ & 1200 & .95 & 8.4 & 2.6 & - \\
\hline $98 / 06 / 11$ & 0200 & $98 / 06 / 12$ & 1100 & .93 & 4.1 & 1.3 & 13 \\
\hline $98 / 06 / 18$ & 1100 & $98 / 06 / 20$ & 1000 & 2.27 & 29 & 64 & 330 \\
\hline $98 / 06 / 27$ & 0200 & $98 / 06 / 29$ & 1800 & 2.13 & 31 & 38 & 220 \\
\hline $98 / 09 / 14$ & 0200 & $98 / 09 / 16$ & 1600 & 2.46 & 11 & 1.3 & 28 \\
\hline \multicolumn{8}{|c|}{ Garfoot Creek } \\
\hline $84 / 10 / 18$ & 1200 & $84 / 10 / 19$ & 2200 & 2.64 & 3.1 & 37 & 210 \\
\hline $84 / 10 / 31$ & 2400 & $84 / 11 / 01$ & 1800 & 1.13 & 1.1 & 16 & 76 \\
\hline $84 / 12 / 27$ & 2200 & $84 / 12 / 29$ & 0900 & $\mathrm{~s} / \mathrm{m}$ & 2.4 & 45 & 140 \\
\hline $85 / 02 / 21$ & 0200 & $85 / 02 / 25$ & 0100 & $\mathrm{~s} / \mathrm{m}$ & 6.3 & 62 & 470 \\
\hline $85 / 07 / 24$ & 1915 & $85 / 07 / 26$ & 0500 & 6.56 & 7.5 & 65 & 710 \\
\hline
\end{tabular}


Appendix. Storm-load data for rural watershed-management evaluation monitoring sites, Wisconsin, water years ${ }^{1}$ 1985-98-Continued

[yr, year; mo, month; d, day; $h$, hour; in., inches; $\mathrm{Mft}^{3}$, million cubic feet; $\mathrm{lb}$, pounds; s/m, snowmelt; --, no data]

\begin{tabular}{|c|c|c|c|c|c|c|c|}
\hline \multicolumn{2}{|c|}{ Start of storm } & \multicolumn{2}{|c|}{ End of storm } & \multirow[b]{2}{*}{$\begin{array}{l}\text { Precipitation } \\
\text { (in.) }\end{array}$} & \multirow[b]{2}{*}{$\begin{array}{l}\text { Streamflow } \\
\text { volume } \\
\left(\mathrm{Mft}^{3}\right)\end{array}$} & \multicolumn{2}{|c|}{ Loads } \\
\hline $\begin{array}{c}\text { Date } \\
\text { (yr/mo/d) }\end{array}$ & $\begin{array}{l}\text { Time } \\
(24 \mathrm{~h})\end{array}$ & $\begin{array}{c}\text { Date } \\
\text { (yr/mo/d) }\end{array}$ & $\begin{array}{l}\text { Time } \\
(24 \mathrm{~h})\end{array}$ & & & $\begin{array}{l}\text { Suspended- } \\
\text { sollds load } \\
\text { (tons) }\end{array}$ & $\begin{array}{l}\text { Total- } \\
\text { phosphorus } \\
\text { load } \\
\text { (Ib) }\end{array}$ \\
\hline \multicolumn{8}{|c|}{ Garfoot Creek - Continued } \\
\hline $85 / 09 / 04$ & 2400 & $85 / 09 / 05$ & 1300 & 1.38 & .49 & 1.7 & 22 \\
\hline $85 / 09 / 09$ & 0015 & $85 / 09 / 09$ & 2100 & 1.63 & 2.2 & 17 & 130 \\
\hline $85 / 09 / 23$ & 0300 & $85 / 09 / 24$ & 0300 & 1.20 & .57 & 1.9 & - \\
\hline $85 / 10 / 11$ & 2345 & $85 / 10 / 12$ & 2100 & .85 & 1.1 & 14 & -- \\
\hline $85 / 10 / 23$ & 1600 & $85 / 10 / 24$ & 0700 & .70 & .62 & 9.8 & 46 \\
\hline $85 / 10 / 31$ & 1626 & $85 / 11 / 02$ & 1400 & 2.79 & 5.3 & 34 & 370 \\
\hline $85 / 11 / 18$ & 0300 & $85 / 11 / 19$ & 0900 & .73 & 1.6 & 17 & 98 \\
\hline $86 / 03 / 09$ & 1600 & $86 / 03 / 11$ & 0600 & $\mathrm{~s} / \mathrm{m}$ & 1.7 & 26 & 110 \\
\hline $86 / 03 / 16$ & 1200 & $86 / 03 / 20$ & 0200 & $\mathrm{~s} / \mathrm{m}$ & 7.7 & 59 & 610 \\
\hline $86 / 05 / 15$ & 1400 & $86 / 05 / 16$ & 0500 & .72 & .53 & 14 & 27 \\
\hline $86 / 05 / 17$ & 0100 & $86 / 05 / 18$ & 0400 & 1.15 & 1,2 & 15 & 75 \\
\hline $89 / 10 / 05$ & 0930 & $89 / 10 / 06$ & 0600 & - & .21 & .27 & 6.4 \\
\hline $90 / 01 / 16$ & 1845 & $90 / 01 / 17$ & 2200 & $\mathrm{~s} / \mathrm{m}$ & 1.4 & 13 & 190 \\
\hline $90 / 03 / 11$ & 0600 & $90 / 03 / 12$ & 0400 & .48 & 2.9 & 53 & 330 \\
\hline $90 / 03 / 13$ & 0600 & $90 / 03 / 14$ & 1300 & .76 & 1.3 & 30 & 160 \\
\hline $90 / 03 / 14$ & 1600 & $90 / 03 / 15$ & 1500 & 1.12 & 2.0 & 31 & 230 \\
\hline $90 / 06 / 02$ & 1300 & $90 / 06 / 03$ & 0100 & 1.48 & .42 & 23 & 100 \\
\hline $90 / 06 / 28$ & 2330 & $90 / 06 / 29$ & 2300 & 2.45 & 3.0 & 77 & 530 \\
\hline $90 / 08 / 19$ & 1630 & $90 / 08 / 20$ & 1200 & - & .81 & 4.6 & 61 \\
\hline $91 / 03 / 01$ & 0945 & $91 / 03 / 02$ & 2200 & 1.51 & 3.2 & 53 & 370 \\
\hline $91 / 03 / 22$ & 2130 & $91 / 03 / 23$ & 0700 & .74 & .33 & 4.2 & 28 \\
\hline $91 / 04 / 12$ & 1500 & $91 / 04 / 13$ & 1400 & 1.74 & 2.2 & 74 & 210 \\
\hline $91 / 04 / 14$ & 0600 & $91 / 04 / 14$ & 2400 & .99 & 1.9 & 58 & 200 \\
\hline $91 / 08 / 08$ & 0200 & $91 / 08 / 08$ & 1500 & 2.34 & .30 & - & 12 \\
\hline $91 / 11 / 01$ & 0900 & $91 / 11 / 02$ & 0100 & 1.40 & 1.3 & 15 & 150 \\
\hline $91 / 11 / 29$ & 2000 & $91 / 11 / 30$ & 1300 & .87 & .98 & 13 & 76 \\
\hline $92 / 02 / 26$ & 1400 & $92 / 02 / 27$ & 0100 & $\mathrm{~s} / \mathrm{m}$ & .30 & - & 11 \\
\hline $92 / 02 / 27$ & 1045 & $92 / 02 / 28$ & 0100 & $\mathrm{~s} / \mathrm{m}$ & .68 & 9.0 & 54 \\
\hline $92 / 02 / 28$ & 1130 & $92 / 02 / 28$ & 2400 & $\mathrm{~s} / \mathrm{m}$ & .44 & 1.5 & 21 \\
\hline $92 / 09 / 16$ & 1200 & $92 / 09 / 17$ & 0330 & 1.34 & .69 & 7.4 & 46 \\
\hline $92 / 09 / 18$ & 0330 & $92 / 09 / 18$ & 1800 & .89 & .70 & 5.2 & 48 \\
\hline $92 / 11 / 19$ & 2000 & $92 / 11 / 21$ & 2300 & 2.68 & 3.4 & 43 & 420 \\
\hline $92 / 12 / 15$ & 1600 & $92 / 12 / 16$ & 1200 & 1.30 & 1.2 & 7.4 & 400 \\
\hline $93 / 03 / 24$ & 1300 & $93 / 03 / 25$ & 0830 & $\mathrm{~s} / \mathrm{m}$ & 2.1 & 24 & 240 \\
\hline $93 / 03 / 25$ & 1030 & $93 / 03 / 26$ & 1000 & $\mathrm{~s} / \mathrm{m}$ & 3.4 & 41 & 300 \\
\hline $93 / 03 / 26$ & 1300 & $93 / 03 / 27$ & 0500 & $\mathrm{~s} / \mathrm{m}$ & 1.7 & 14 & 130 \\
\hline $93 / 03 / 27$ & 1240 & $93 / 03 / 28$ & 0400 & $\mathrm{~s} / \mathrm{m}$ & 1.3 & 9.1 & 100 \\
\hline
\end{tabular}


Appendix. Storm-load data for rural watershed-management evaluation monitoring sites, Wisconsin, water years 1 1985-98-Continued

[yr, year; mo, month; d, day; h, hour; in., inches; Mft ${ }^{3}$, million cubic feet; lb, pounds; s/m, snowmelt; --, no data]

\begin{tabular}{|c|c|c|c|c|c|c|c|}
\hline \multicolumn{2}{|c|}{ Start of storm } & \multicolumn{2}{|c|}{ End of storm } & \multirow[b]{2}{*}{$\begin{array}{l}\text { Preclpitation } \\
\text { (in.) }\end{array}$} & \multirow[b]{2}{*}{$\begin{array}{l}\text { Streamfiow } \\
\text { volume } \\
\left(\mathrm{Mft}^{3}\right)\end{array}$} & \multicolumn{2}{|c|}{ Loads } \\
\hline $\begin{array}{c}\text { Date } \\
(y r / m o / d)\end{array}$ & $\begin{array}{l}\text { Time } \\
(24 \mathrm{~h})\end{array}$ & $\begin{array}{c}\text { Date } \\
\text { (yr/mo/d) }\end{array}$ & $\begin{array}{l}\text { Time } \\
(24 \mathrm{~h})\end{array}$ & & & $\begin{array}{l}\text { Suspended- } \\
\text { solids load } \\
\text { (tons) }\end{array}$ & $\begin{array}{l}\text { Total- } \\
\text { phosphorus } \\
\text { load } \\
\text { (Ib) }\end{array}$ \\
\hline \multicolumn{8}{|c|}{ Garfoot Creek-Continued } \\
\hline $93 / 03 / 28$ & 1000 & $93 / 03 / 29$ & 0300 & $\mathrm{~s} / \mathrm{m}$ & 2.7 & 44 & 290 \\
\hline $93 / 03 / 31$ & 0400 & $93 / 04 / 01$ & 0400 & $\mathrm{~s} / \mathrm{m}$ & 3.7 & 28 & 210 \\
\hline $93 / 04 / 07$ & 2300 & $93 / 04 / 08$ & 1700 & .62 & 1.3 & 13 & 60 \\
\hline $93 / 04 / 15$ & 0100 & $93 / 04 / 16$ & 1200 & 1.55 & 4.2 & 35 & 240 \\
\hline $93 / 04 / 19$ & 1300 & $93 / 04 / 20$ & 2300 & 1.69 & 3.8 & 37 & 180 \\
\hline $93 / 06 / 07$ & 1045 & $93 / 06 / 08$ & 2000 & 1.97 & 2.8 & 31 & 180 \\
\hline $93 / 06 / 17$ & 1800 & $93 / 06 / 18$ & 1200 & 1.09 & .99 & 13 & 54 \\
\hline 93/07/05 & 0500 & $93 / 07 / 07$ & 0200 & 3.98 & 7.7 & 130 & 730 \\
\hline $93 / 07 / 08$ & 1300 & $93 / 07 / 10$ & 0400 & 1.81 & 5.9 & 110 & 490 \\
\hline $93 / 07 / 10$ & 1800 & $93 / 07 / 11$ & 0500 & .45 & 1.1 & 12 & 63 \\
\hline $93 / 07 / 25$ & 0300 & $93 / 07 / 25$ & 2400 & 1.48 & 2.5 & 43 & 220 \\
\hline $93 / 07 / 27$ & 2200 & $93 / 07 / 28$ & 1500 & .44 & .92 & 5.92 & 38 \\
\hline $93 / 08 / 15$ & 0500 & $93 / 08 / 16$ & 1300 & 2.35 & 3.6 & 30.8 & 230 \\
\hline $93 / 08 / 23$ & 1600 & $93 / 08 / 24$ & 0700 & 1.26 & 1.3 & 14.2 & 65 \\
\hline $93 / 09 / 13$ & 1000 & $93 / 09 / 15$ & 0500 & 2.27 & 2.7 & 18.6 & 140 \\
\hline $94 / 02 / 19$ & 0100 & $94 / 02 / 21$ & 0700 & - & 6.4 & 74 & 650 \\
\hline $94 / 03 / 05$ & 1200 & $94 / 03 / 06$ & 0500 & - & 1.2 & 9 & 89 \\
\hline $94 / 03 / 06$ & 1100 & $94 / 03 / 07$ & 0500 & - & 1.2 & 5.7 & 63 \\
\hline $94 / 08 / 10$ & 1200 & $94 / 08 / 11$ & 1500 & -- & 1.4 & 12 & 76 \\
\hline $94 / 09 / 14$ & 0500 & $94 / 09 / 14$ & 2000 & -- & .59 & 5.2 & 22 \\
\hline $94 / 11 / 27$ & 1015 & $94 / 11 / 28$ & 0800 & 1.28 & 12 & 14 & 74 \\
\hline $95 / 03 / 11$ & 1000 & $95 / 03 / 12$ & 0800 & $\mathrm{~s} / \mathrm{m}$ & 13 & 24 & 99 \\
\hline $95 / 03 / 20$ & 0200 & $95 / 03 / 21$ & 1500 & .74 & 14 & 2.9 & 31 \\
\hline $95 / 04 / 10$ & 1300 & $95 / 04 / 11$ & 1200 & .54 & 9.4 & 1.9 & 19 \\
\hline $95 / 04 / 18$ & 0500 & $95 / 04 / 19$ & 0200 & .96 & 13 & 6.8 & 56 \\
\hline $95 / 05 / 09$ & 2000 & $95 / 05 / 10$ & 2400 & .60 & 14 & 3.2 & 31 \\
\hline $95 / 05 / 27$ & 1400 & $95 / 05 / 28$ & 1800 & 2.40 & 29 & 43 & 180 \\
\hline $95 / 08 / 16$ & 1600 & $95 / 08 / 17$ & 1800 & 2.33 & 18 & 25 & 120 \\
\hline $95 / 08 / 19$ & 0800 & $95 / 08 / 20$ & 0900 & 1.03 & 15 & 14 & 69 \\
\hline $95 / 10 / 05$ & 2100 & $95 / 10 / 07$ & 1500 & 2.28 & 21 & 20 & 110 \\
\hline $95 / 11 / 01$ & 1300 & $95 / 11 / 03$ & 1200 & 1.71 & 27 & 34 & 130 \\
\hline $96 / 01 / 17$ & 2000 & $96 / 01 / 20$ & 0400 & .89 & 35 & 120 & 440 \\
\hline $96 / 02 / 09$ & 0900 & $96 / 02 / 12$ & 0800 & $\mathrm{~s} / \mathrm{m}$ & 32 & 190 & 300 \\
\hline $96 / 02 / 26$ & 1600 & $96 / 02 / 28$ & 1600 & .55 & 41 & 61 & 300 \\
\hline $96 / 05 / 09$ & 2300 & $96 / 05 / 11$ & 2200 & 1.78 & 45 & 98 & 560 \\
\hline $96 / 06 / 01$ & 1600 & $96 / 06 / 02$ & 2000 & 1.32 & 13 & 7.8 & 46 \\
\hline
\end{tabular}


Appendix. Storm-load data for rural watershed-management evaluation monitoring sites, Wisconsin, water years ${ }^{1}$ 1985-98-Continued

[yr, year; mo, month; d. day; $h$, hour: in., inches: $\mathrm{Mft}^{3}$, million cubic feet; $1 \mathrm{~b}$, pounds; s/m, snowmelt; --. no data]

\begin{tabular}{|c|c|c|c|c|c|c|c|}
\hline \multicolumn{2}{|c|}{ Start of storm } & \multicolumn{2}{|c|}{ End of storm } & \multirow[b]{2}{*}{$\begin{array}{l}\text { Precipitation } \\
\text { (in.) }\end{array}$} & \multirow[b]{2}{*}{$\begin{array}{c}\text { Streamflow } \\
\text { volume } \\
\left(\mathrm{Mft}^{3}\right)\end{array}$} & \multicolumn{2}{|c|}{ Loads } \\
\hline $\begin{array}{c}\text { Date } \\
\text { (yr/mo/d) }\end{array}$ & $\begin{array}{l}\text { Time } \\
(24 \text { h) }\end{array}$ & $\begin{array}{c}\text { Date } \\
(\mathrm{yr} / \mathrm{mo} / \mathrm{d})\end{array}$ & $\begin{array}{l}\text { Time } \\
(24 \mathrm{~h})\end{array}$ & & & $\begin{array}{l}\text { Suspended- } \\
\text { sollds load } \\
\text { (tons) }\end{array}$ & $\begin{array}{c}\text { Total- } \\
\text { phosphorus } \\
\text { load } \\
\text { (lb) }\end{array}$ \\
\hline \multicolumn{8}{|c|}{ Garfoot Creek-Continued } \\
\hline $96 / 06 / 06$ & 0200 & $96 / 06 / 08$ & 2000 & 1.77 & 29 & 15 & 100 \\
\hline $96 / 06 / 16$ & 2300 & $96 / 06 / 18$ & 2200 & 3.43 & 82 & 60 & 430 \\
\hline $96 / 07 / 18$ & 0100 & $96 / 07 / 19$ & 1000 & 1.92 & 18 & 17 & 85 \\
\hline $96 / 08 / 05$ & 1800 & $96 / 08 / 08$ & 0500 & 2.39 & 24 & 16 & 77 \\
\hline $96 / 10 / 29$ & 1000 & $96 / 10 / 30$ & 1400 & 1.35 & 12 & 3.6 & 33 \\
\hline $97 / 02 / 17$ & 2000 & $97 / 02 / 19$ & 0600 & $\mathrm{~s} / \mathrm{m}$ & 32 & 48 & 310 \\
\hline $97 / 02 / 20$ & 1400 & $97 / 02 / 22$ & 1400 & .87 & 42 & 43 & 300 \\
\hline $97 / 03 / 01$ & 0100 & $97 / 03 / 02$ & 0500 & $\mathrm{~s} / \mathrm{m}$ & 26 & 34 & 210 \\
\hline $97 / 03 / 09$ & 0600 & $97 / 03 / 10$ & 1000 & $\mathrm{~s} / \mathrm{m}$ & 14 & 17 & 81 \\
\hline $97 / 04 / 30$ & 1900 & $97 / 05 / 01$ & 2100 & 1.62 & 14 & 8.5 & 52 \\
\hline $97 / 06 / 15$ & 1730 & $97 / 06 / 17$ & 0400 & 1.99 & 10 & 5.3 & 37 \\
\hline $97 / 06 / 21$ & 0800 & $97 / 06 / 22$ & 0700 & 1.23 & 7.3 & 3.2 & 22 \\
\hline $97 / 07 / 08$ & 0400 & $97 / 07 / 08$ & 2300 & 1.51 & 8.1 & 5.6 & 30 \\
\hline $97 / 07 / 21$ & 0100 & $97 / 07 / 21$ & 2100 & .89 & 6.2 & 2.7 & 20 \\
\hline $97 / 07 / 27$ & 0700 & $97 / 07 / 28$ & 0200 & 1.04 & 7.6 & 4 & 22 \\
\hline $97 / 08 / 12$ & 0400 & $97 / 08 / 13$ & 0200 & 1.13 & 5.9 & 1.4 & 12 \\
\hline $98 / 02 / 15$ & 1200 & $98 / 02 / 18$ & 0900 & .12 & 23 & 5.5 & 56 \\
\hline $98 / 03 / 30$ & 1200 & $98 / 04 / 02$ & 0100 & 4.49 & 130 & 240 & 1,400 \\
\hline $98 / 04 / 07$ & 1800 & $98 / 04 / 10$ & 0500 & 1.29 & 26 & 9.9 & 36 \\
\hline $98 / 04 / 13$ & 1000 & $98 / 04 / 17$ & 1400 & 1.57 & 53 & -- & 180 \\
\hline $98 / 05 / 07$ & 0600 & $98 / 05 / 08$ & 1200 & .71 & 14 & - & 34 \\
\hline $98 / 06 / 11$ & 0400 & $98 / 06 / 12$ & 1500 & .36 & 13 & - & 39 \\
\hline $98 / 06 / 18$ & 1200 & $98 / 06 / 19$ & 2300 & .78 & 46 & 48 & 270 \\
\hline $98 / 06 / 27$ & 2200 & $98 / 06 / 29$ & 0400 & .83 & 50 & 52 & 320 \\
\hline $98 / 07 / 03$ & 1000 & $98 / 07 / 04$ & 1800 & 1.05 & 27 & 37 & 140 \\
\hline $98 / 09 / 14$ & 0400 & $98 / 09 / 15$ & 1500 & 2.84 & 23 & 7.7 & 120 \\
\hline \multicolumn{8}{|c|}{ Eagle Creek } \\
\hline $91 / 04 / 29$ & 0200 & $91 / 04 / 29$ & 2200 & 1.81 & 5.1 & 2,100 & 3,800 \\
\hline $91 / 05 / 05$ & 0800 & $91 / 05 / 05$ & 2230 & 1.29 & 1.7 & 61 & 210 \\
\hline $91 / 05 / 15$ & 2130 & $91 / 05 / 17$ & 0200 & .85 & 6.9 & 3,200 & 4,700 \\
\hline $91 / 05 / 31$ & 0900 & $91 / 05 / 31$ & 2000 & .50 & 1.2 & 250 & 280 \\
\hline $91 / 07 / 21$ & 1715 & $91 / 07 / 21$ & 2400 & 1.99 & 1.6 & 220 & 430 \\
\hline $91 / 08 / 07$ & 1540 & $91 / 08 / 08$ & 1500 & 1.88 & 1.6 & 62 & 140 \\
\hline $91 / 10 / 23$ & 2325 & $91 / 10 / 24$ & 1200 & 1.21 & .88 & 52 & 200 \\
\hline $91 / 11 / 01$ & 0050 & $91 / 11 / 01$ & 2300 & 2.75 & 7.0 & 620 & 1,400 \\
\hline $91 / 11 / 17$ & 1900 & $91 / 11 / 18$ & 1200 & 1.15 & 1.9 & 120 & 250 \\
\hline
\end{tabular}


Appendix. Storm-load data for rural watershed-management evaluation monitoring sites, Wisconsin, water years ${ }^{1}$ 1985-98-Continued

[yr, year; mo, month; d, day; h, hour; in., inches; Mft ${ }^{3}$, million cubic feet; lb, pounds; s/m, snowmelt; --, no data]

\begin{tabular}{|c|c|c|c|c|c|c|c|}
\hline \multicolumn{2}{|c|}{ Start of storm } & \multicolumn{2}{|c|}{ End of storm } & \multirow[b]{2}{*}{$\begin{array}{l}\text { Precipitation } \\
\quad \text { (in.) }\end{array}$} & \multirow[b]{2}{*}{$\begin{array}{c}\text { Streamflow } \\
\text { volume } \\
\left(\mathrm{Mft}^{3}\right)\end{array}$} & \multicolumn{2}{|c|}{ Loads } \\
\hline $\begin{array}{c}\text { Date } \\
\text { (yr/mo/d) }\end{array}$ & $\begin{array}{l}\text { Time } \\
(24 \mathrm{~h})\end{array}$ & $\begin{array}{c}\text { Date } \\
\text { (yr/mo/d) }\end{array}$ & $\begin{array}{l}\text { Time } \\
(24 \mathrm{~h})\end{array}$ & & & $\begin{array}{l}\text { Suspended- } \\
\text { solids load } \\
\text { (tons) }\end{array}$ & $\begin{array}{l}\text { Total- } \\
\text { phosphorus } \\
\text { load } \\
\text { (lb) }\end{array}$ \\
\hline \multicolumn{8}{|c|}{ Eagle Creek-Continued } \\
\hline $92 / 03 / 01$ & 1100 & $92 / 03 / 02$ & 0400 & $\mathrm{~s} / \mathrm{m}$ & 1.3 & 140 & 220 \\
\hline $92 / 03 / 03$ & 2000 & $92 / 03 / 04$ & 0900 & .41 & .92 & 48 & 130 \\
\hline $92 / 03 / 09$ & 0100 & $92 / 03 / 09$ & 1300 & .82 & 1.1 & 72 & 170 \\
\hline $92 / 04 / 20$ & 1500 & $92 / 04 / 21$ & 0900 & 1.24 & 1.8 & 210 & 300 \\
\hline $92 / 05 / 16$ & 1645 & $92 / 05 / 16$ & 2400 & 1.54 & .66 & 83.6 & 160 \\
\hline $92 / 05 / 21$ & 1730 & $92 / 05 / 21$ & 2200 & .51 & .24 & 6.3 & 22 \\
\hline $92 / 05 / 22$ & 1815 & $92 / 05 / 23$ & 0300 & .44 & .47 & 26 & 84 \\
\hline $92 / 07 / 13$ & 1400 & $92 / 07 / 13$ & 2400 & 1.27 & .73 & 43 & 80 \\
\hline $92 / 08 / 01$ & 1900 & $92 / 08 / 02$ & 0200 & 1.03 & .49 & 16 & 31 \\
\hline $92 / 09 / 16$ & 0200 & $92 / 09 / 16$ & 2400 & 3.99 & 1.2 & 1,700 & 3,300 \\
\hline $93 / 03 / 26$ & 1200 & $93 / 03 / 27$ & 0200 & $\mathrm{~s} / \mathrm{m}$ & 1.1 & 35 & 87 \\
\hline $93 / 03 / 29$ & 1100 & $93 / 03 / 29$ & 2400 & $\mathrm{~s} / \mathrm{m}$ & 9.9 & 27 & 42 \\
\hline $93 / 03 / 30$ & 1300 & $93 / 03 / 31$ & 2100 & 1.67 & 4.7 & 420 & 610 \\
\hline 93/04/11 & 0200 & $93 / 04 / 12$ & 0600 & .79 & 2.4 & 50 & 100 \\
\hline $93 / 04 / 18$ & 2100 & $93 / 04 / 20$ & 0600 & 2.22 & 7.0 & 450 & 960 \\
\hline $93 / 04 / 27$ & 0100 & $93 / 04 / 27$ & 1400 & 1.02 & 1.4 & 74 & 180 \\
\hline $93 / 06 / 08$ & 1500 & $93 / 06 / 09$ & 0400 & 1.47 & 4.4 & 950 & 2,000 \\
\hline $93 / 07 / 02$ & 0010 & $93 / 07 / 02$ & 1100 & 1.47 & 5.5 & 420 & 1,100 \\
\hline $93 / 07 / 03$ & 1400 & $93 / 07 / 04$ & 0600 & 1.06 & 6.1 & 1,500 & 3,000 \\
\hline $93 / 07 / 27$ & 1715 & $93 / 07 / 28$ & 0400 & .76 & 1.5 & 120 & 220 \\
\hline $93 / 08 / 09$ & 0600 & $93 / 08 / 09$ & 2000 & 1.09 & 2.8 & 310 & 540 \\
\hline $93 / 08 / 15$ & 0400 & $93 / 08 / 15$ & 1800 & 1.18 & 2.2 & 73 & 160 \\
\hline $93 / 08 / 18$ & 0900 & $93 / 08 / 18$ & 2100 & 1.30 & 3.6 & 290 & 640 \\
\hline $93 / 08 / 30$ & 0400 & $93 / 08 / 30$ & 2000 & 1.69 & 4.6 & 410 & 1,000 \\
\hline $93 / 09 / 13$ & 1000 & $93 / 09 / 14$ & 1100 & 1.72 & 3.6 & 120 & 300 \\
\hline $94 / 02 / 18$ & 1300 & $94 / 02 / 20$ & 0900 & - & 12 & 1,700 & 3,400 \\
\hline $94 / 03 / 04$ & 1100 & $94 / 03 / 05$ & 0800 & - & 3.6 & 380 & 790 \\
\hline $94 / 03 / 05$ & 1100 & $94 / 03 / 06$ & 1000 & -- & 2.9 & 130 & 450 \\
\hline $94 / 04 / 15$ & 0140 & $94 / 04 / 16$ & 0600 & - & 2.2 & 67 & 140 \\
\hline $94 / 04 / 24$ & 2000 & $94 / 04 / 25$ & 1900 & - & 2.0 & 54 & 110 \\
\hline $94 / 04 / 26$ & 0010 & $94 / 04 / 27$ & 0200 & -- & 5.2 & 1,900 & 2,900 \\
\hline $94 / 07 / 07$ & 1300 & $94 / 07 / 08$ & 1100 & - & 1.9 & 75 & 170 \\
\hline $94 / 08 / 10$ & 0110 & $94 / 08 / 11$ & 1000 & - & 6.0 & 390 & 800 \\
\hline $94 / 08 / 18$ & 0315 & $94 / 08 / 18$ & 2100 & -- & 1.7 & 95 & 180 \\
\hline $94 / 08 / 30$ & 0835 & $94 / 08 / 31$ & 0300 & -- & 1.5 & 51 & 110 \\
\hline $94 / 09 / 13$ & 2035 & $94 / 09 / 15$ & 0300 & -- & 5.5 & 340 & 920 \\
\hline $94 / 09 / 23$ & 1615 & $94 / 09 / 24$ & 1100 & -- & 1.4 & 30 & 63 \\
\hline
\end{tabular}


Appendix. Storm-load data for rural watershed-management evaluation monitoring sites, Wisconsin, water years ${ }^{1}$ 1985-98-Continued

[yr, year; mo, month; d, day; h, hour; in., inches; $\mathrm{Mft}^{3}$, million cubic feet; lb, pounds; s/m, snowmelt; --, no data]

\begin{tabular}{|c|c|c|c|c|c|c|c|}
\hline \multicolumn{2}{|c|}{ Start of storm } & \multicolumn{2}{|c|}{ End of storm } & \multirow[b]{2}{*}{$\begin{array}{l}\text { Precipitation } \\
\text { (In.) }\end{array}$} & \multirow[b]{2}{*}{$\begin{array}{c}\text { Streamflow } \\
\text { volume } \\
\left(\mathrm{Mft}^{3}\right)\end{array}$} & \multicolumn{2}{|c|}{ Loads } \\
\hline $\begin{array}{c}\text { Date } \\
\text { (yr/mo/d) }\end{array}$ & $\begin{array}{l}\text { Time } \\
(24 \mathrm{~h})\end{array}$ & $\begin{array}{c}\text { Dste } \\
(\mathrm{yr} / \mathrm{mo} / \mathrm{d})\end{array}$ & $\begin{array}{l}\text { Time } \\
(24 \mathrm{~h})\end{array}$ & & & $\begin{array}{l}\text { Suspended- } \\
\text { sollds load } \\
\text { (tons) }\end{array}$ & $\begin{array}{c}\text { Total- } \\
\text { phosphorus } \\
\text { load } \\
\text { (lb) }\end{array}$ \\
\hline \multicolumn{8}{|c|}{ Eagle Creek-Continued } \\
\hline $94 / 10 / 17$ & 1600 & $94 / 10 / 18$ & 1200 & .79 & 15 & 28 & 80 \\
\hline $95 / 08 / 13$ & 0400 & $95 / 08 / 13$ & 1700 & 1.55 & 8.2 & 11 & 34 \\
\hline $95 / 08 / 13$ & 2000 & $95 / 08 / 14$ & 2000 & 4.81 & 210 & 5,300 & 10,000 \\
\hline $95 / 10 / 23$ & 0830 & $95 / 10 / 24$ & 0200 & 1.25 & 9.7 & 4 & 6.7 \\
\hline $96 / 03 / 13$ & 1000 & $96 / 03 / 14$ & 0700 & $\mathrm{~s} / \mathrm{m}$ & 28 & 230 & 570 \\
\hline $96 / 03 / 14$ & 1000 & $96 / 03 / 15$ & 0800 & $\mathrm{~s} / \mathrm{m}$ & 23 & 77 & 320 \\
\hline $96 / 03 / 15$ & 1100 & $96 / 03 / 16$ & 0600 & $\mathrm{~s} / \mathrm{m}$ & 16 & 58 & 150 \\
\hline $96 / 03 / 16$ & 1200 & $96 / 03 / 17$ & 0400 & $\mathrm{~s} / \mathrm{m}$ & 12 & 57 & 87 \\
\hline $96 / 03 / 24$ & 0200 & $96 / 03 / 25$ & 0900 & 1.55 & 88 & 1,500 & 2,900 \\
\hline $96 / 06 / 16$ & 1900 & $96 / 06 / 17$ & 1300 & 1.29 & 10 & 12 & 30 \\
\hline $96 / 06 / 17$ & 1500 & $96 / 06 / 18$ & 1100 & .63 & 13 & 14 & 32 \\
\hline \multicolumn{8}{|c|}{ Joos Valley Creek } \\
\hline $90 / 08 / 17$ & 1850 & $90 / 08 / 18$ & 0200 & 1.37 & .96 & 170 & 420 \\
\hline $90 / 08 / 26$ & 0545 & $90 / 08 / 26$ & 1500 & 1.75 & 2.8 & 750 & 1,600 \\
\hline $91 / 04 / 29$ & 0200 & $91 / 04 / 29$ & 1600 & 2.11 & 1.7 & 840 & 1,500 \\
\hline $91 / 05 / 05$ & 0730 & $91 / 05 / 05$ & 2000 & 1.25 & .64 & 26 & 57 \\
\hline $91 / 05 / 15$ & 2000 & $91 / 05 / 17$ & 0200 & 1.21 & 1.8 & 390 & 850 \\
\hline $91 / 05 / 31$ & 0850 & $91 / 05 / 31$ & 1900 & .57 & .40 & 36 & 78 \\
\hline $91 / 07 / 21$ & 1710 & $91 / 07 / 22$ & 1100 & 1.24 & .68 & 27 & 70 \\
\hline $91 / 08 / 07$ & 1500 & $91 / 08 / 08$ & 1100 & 2.27 & .63 & 11 & 34 \\
\hline $91 / 10 / 23$ & 2250 & $91 / 10 / 24$ & 1300 & .83 & .34 & 3.4 & 12 \\
\hline $91 / 10 / 31$ & 2200 & $91 / 11 / 01$ & 2200 & 2.87 & 2.1 & 110 & 330 \\
\hline $91 / 11 / 17$ & 1800 & $91 / 11 / 18$ & 1400 & 1.21 & .96 & 14 & 62 \\
\hline $92 / 03 / 01$ & 1000 & $92 / 03 / 02$ & 0400 & $\mathrm{~s} / \mathrm{m}$ & .63 & 16 & 68 \\
\hline $92 / 03 / 03$ & 1400 & $92 / 03 / 04$ & 0800 & .37 & .47 & 1.5 & 11 \\
\hline $92 / 03 / 08$ & 2400 & $92 / 03 / 09$ & 1100 & .86 & .45 & 20 & 49 \\
\hline $92 / 04 / 20$ & 1300 & $92 / 04 / 21$ & 0700 & 1.24 & .77 & 56 & 120 \\
\hline $92 / 05 / 16$ & 1500 & $92 / 05 / 16$ & 2200 & 1.62 & .34 & 54 & 110 \\
\hline $92 / 05 / 21$ & 1700 & $92 / 05 / 21$ & 2400 & .74 & .22 & 13 & 35 \\
\hline $92 / 05 / 22$ & 1800 & $92 / 05 / 23$ & 0300 & .49 & .27 & 12 & 31 \\
\hline $92 / 06 / 17$ & 0400 & $92 / 06 / 17$ & 1800 & .57 & .25 & 2.8 & 7.7 \\
\hline $92 / 07 / 02$ & 0500 & $92 / 07 / 02$ & 1500 & .72 & .23 & 4.2 & 9.2 \\
\hline $92 / 07 / 13$ & 1300 & $92 / 07 / 14$ & 0200 & 1.32 & .40 & 7.1 & 21 \\
\hline $92 / 07 / 22$ & 1000 & $92 / 07 / 23$ & 0300 & 1.19 & .37 & 1.4 & 5.7 \\
\hline $92 / 08 / 01$ & 1800 & $92 / 08 / 02$ & 1300 & 1.24 & .57 & 24 & 73 \\
\hline $92 / 09 / 16$ & 0100 & $92 / 09 / 16$ & 2200 & 4.19 & 5.4 & 910 & 1,700 \\
\hline
\end{tabular}


Appendix. Storm-load data for rural watershed-management evaluation monitoring sites, Wisconsin, water years ${ }^{1}$ 1985-98-Continued

[yr, year; mo, month; d, day; $h$, hour; in., inches; $\mathrm{Mft}^{3}$, million cubic feet; lb, pounds; s/m, snowmelt; --, no data]

\begin{tabular}{|c|c|c|c|c|c|c|c|}
\hline \multicolumn{2}{|c|}{ Start of storm } & \multicolumn{2}{|c|}{ End of storm } & \multirow[b]{2}{*}{$\begin{array}{l}\text { Precipltation } \\
\text { (in.) }\end{array}$} & \multirow[b]{2}{*}{$\begin{array}{c}\text { Streamflow } \\
\text { volume } \\
\left(\mathrm{Mft}^{3}\right)\end{array}$} & \multicolumn{2}{|c|}{ Loads } \\
\hline $\begin{array}{c}\text { Date } \\
\text { (yr/mo/d) }\end{array}$ & $\begin{array}{l}\text { Tlme } \\
(24 \mathrm{~h})\end{array}$ & $\begin{array}{c}\text { Date } \\
(\mathrm{yr} / \mathrm{mo} / \mathrm{d})\end{array}$ & $\begin{array}{l}\text { Time } \\
(24 \mathrm{~h})\end{array}$ & & & $\begin{array}{l}\text { Suspended- } \\
\text { solids load } \\
\text { (tons) }\end{array}$ & $\begin{array}{l}\text { Total- } \\
\text { phosphorus } \\
\text { load } \\
\text { (lb) }\end{array}$ \\
\hline \multicolumn{8}{|c|}{ Joos Valley Creek-Continued } \\
\hline $93 / 03 / 24$ & 1100 & $93 / 03 / 25$ & 0500 & $\mathrm{~s} / \mathrm{m}$ & .38 & 1.4 & 14 \\
\hline $93 / 03 / 26$ & 1300 & $93 / 03 / 27$ & 0200 & $\mathrm{~s} / \mathrm{m}$ & .47 & 8.3 & 56 \\
\hline $93 / 03 / 30$ & 1100 & $93 / 03 / 31$ & 2000 & 1.50 & 2.1 & 86 & 25 \\
\hline $93 / 04 / 11$ & 0100 & $93 / 04 / 12$ & 0200 & .53 & .87 & 4.0 & 15 \\
\hline $93 / 04 / 16$ & 1200 & $93 / 04 / 17$ & 0100 & .64 & .60 & 4.2 & 16 \\
\hline $93 / 04 / 18$ & 2200 & $93 / 04 / 20$ & 0300 & 2.07 & 2.7 & 130 & 320 \\
\hline $93 / 04 / 27$ & 0100 & $93 / 04 / 28$ & 0200 & 1.07 & 1.5 & 22 & 63 \\
\hline $93 / 06 / 08$ & 1500 & $93 / 06 / 08$ & 2310 & 1.50 & 1.8 & 630 & 900 \\
\hline $93 / 07 / 01$ & 2400 & $93 / 07 / 02$ & 0940 & 1.33 & 1.2 & 180 & 410 \\
\hline $93 / 07 / 03$ & 1400 & $93 / 07 / 03$ & 2100 & .90 & 2.2 & 880 & 1,600 \\
\hline $93 / 07 / 27$ & 1700 & $93 / 07 / 27$ & 2300 & .75 & .54 & 64 & 130 \\
\hline $93 / 08 / 09$ & 0600 & $93 / 08 / 09$ & 1400 & 1.17 & .92 & 110 & 220 \\
\hline $93 / 08 / 15$ & 0300 & $93 / 08 / 15$ & 1500 & 1.19 & .73 & 12 & 330 \\
\hline $93 / 08 / 18$ & 0900 & $93 / 08 / 18$ & 0900 & 1.08 & .87 & 53 & 140 \\
\hline $93 / 08 / 30$ & 0300 & $93 / 08 / 30$ & 1300 & 1.78 & 1.4 & 130 & 290 \\
\hline $94 / 02 / 18$ & 1200 & $94 / 02 / 20$ & 0800 & -- & 5.7 & 740 & 1500 \\
\hline $94 / 03 / 04$ & 1000 & $94 / 03 / 05$ & 0500 & -- & 1.8 & 160 & 350 \\
\hline $94 / 03 / 05$ & 1100 & $94 / 03 / 06$ & 0800 & - & 1.3 & 28 & 250 \\
\hline $94 / 04 / 15$ & 0110 & $94 / 04 / 16$ & 0300 & $\cdots$ & .84 & 16 & 35 \\
\hline $94 / 04 / 24$ & 2110 & $94 / 04 / 26$ & 2100 & - & 2.8 & 670 & 1,200 \\
\hline $94 / 07 / 07$ & 1122 & $94 / 07 / 08$ & 1000 & -- & .77 & 19 & 60 \\
\hline $94 / 08 / 10$ & 0425 & $94 / 08 / 11$ & 1900 & -- & 2.3 & 130 & 300 \\
\hline $94 / 08 / 18$ & 0325 & $94 / 08 / 18$ & 2300 & $\cdots$ & .68 & 22 & 70 \\
\hline $94 / 08 / 13$ & 0740 & $94 / 08 / 30$ & 2100 & - & .5 & 5.1 & 17 \\
\hline $94 / 09 / 13$ & 2035 & $94 / 09 / 14$ & 2300 & - & 2.1 & 150 & 420 \\
\hline $94 / 09 / 23$ & 1550 & $94 / 09 / 23$ & 2300 & -- & .31 & 4.2 & 9.5 \\
\hline $94 / 10 / 17$ & 1700 & $94 / 10 / 18$ & 0800 & .86 & 5.8 & 5 & 16 \\
\hline $95 / 08 / 13$ & 2000 & $95 / 08 / 14$ & 1300 & 5.13 & 110 & 6,200 & 9,800 \\
\hline $95 / 10 / 23$ & 0700 & $95 / 10 / 24$ & 0200 & 1.25 & 4.4 & .39 & 1.8 \\
\hline $96 / 03 / 11$ & 1100 & $96 / 03 / 12$ & 0600 & $\mathrm{~s} / \mathrm{m}$ & 3.6 & .57 & 6.3 \\
\hline $96 / 03 / 12$ & 1100 & $96 / 03 / 13$ & 0900 & $\mathrm{~s} / \mathrm{m}$ & 7.8 & 2.5 & 22 \\
\hline $96 / 03 / 13$ & 1100 & $96 / 03 / 14$ & 1100 & $\mathrm{~s} / \mathrm{m}$ & 20 & 50 & 230 \\
\hline $96 / 03 / 14$ & 1200 & $96 / 03 / 15$ & 0700 & $\mathrm{~s} / \mathrm{m}$ & 14 & 12 & 86 \\
\hline $96 / 03 / 15$ & 1000 & $96 / 03 / 16$ & 0900 & $\mathrm{~s} / \mathrm{m}$ & 11 & 5.5 & 49 \\
\hline $96 / 03 / 16$ & 1300 & $96 / 03 / 17$ & 0900 & $\mathrm{~s} / \mathrm{m}$ & 8.2 & 6.8 & 31 \\
\hline $96 / 03 / 24$ & 0100 & $96 / 03 / 26$ & 0100 & 1.70 & 58 & 940 & 1,800 \\
\hline $96 / 06 / 16$ & 1200 & $96 / 06 / 18$ & 2000 & 2.25 & 14 & 8.9 & 20 \\
\hline
\end{tabular}


Appendix. Storm-load data for rural watershed-management evaluation monitoning sites, Wisconsin, water years ${ }^{1}$ 1985-98-Continued

[yr, year; mo, month; d, day; h, hour; in., inches; $\mathrm{Mft}^{3}$, million cubic feet; lb, pounds; s/m, snowmelt; --, no data]

\begin{tabular}{|c|c|c|c|c|c|c|c|}
\hline \multicolumn{2}{|c|}{ Start of storm } & \multicolumn{2}{|c|}{ End of storm } & \multirow[b]{2}{*}{$\begin{array}{c}\text { Precipltation } \\
\text { (ln.) }\end{array}$} & \multirow[b]{2}{*}{$\begin{array}{l}\text { Streamflow } \\
\text { volume } \\
\left(\mathrm{Mft}^{3}\right)\end{array}$} & \multicolumn{2}{|c|}{ Loads } \\
\hline $\begin{array}{c}\text { Date } \\
(\mathrm{yr} / \mathrm{mo} / \mathrm{d})\end{array}$ & $\begin{array}{l}\text { Time } \\
(24 \mathrm{~h})\end{array}$ & $\begin{array}{c}\text { Date } \\
\text { (yr/mo/d) }\end{array}$ & $\begin{array}{l}\text { Time } \\
(24 \mathrm{~h})\end{array}$ & & & $\begin{array}{l}\text { Suspended- } \\
\text { solids load } \\
\text { (tons) }\end{array}$ & $\begin{array}{c}\text { Total- } \\
\text { phosphorus } \\
\text { load } \\
\text { (lb) }\end{array}$ \\
\hline \multicolumn{8}{|c|}{ Bower Creek } \\
\hline $90 / 10 / 17$ & 2040 & $90 / 10 / 20$ & 0925 & .38 & 3.6 & 12 & 280 \\
\hline $91 / 03 / 01$ & 1500 & $91 / 03 / 04$ & 1100 & 1.05 & 100 & 100 & - \\
\hline $91 / 03 / 05$ & 1700 & $91 / 03 / 08$ & 1500 & $\mathrm{~s} / \mathrm{m}$ & 12 & 13 & 520 \\
\hline $91 / 03 / 18$ & 1300 & $91 / 03 / 25$ & 0900 & $\mathrm{~s} / \mathrm{m}$ & 160 & 160 & 1,800 \\
\hline $91 / 04 / 09$ & 1100 & $91 / 04 / 12$ & 2000 & $\mathrm{~s} / \mathrm{m}$ & 48 & 48 & 460 \\
\hline $91 / 04 / 12$ & 2400 & $91 / 04 / 17$ & 2400 & .71 & 260 & 260 & 1,500 \\
\hline $91 / 06 / 14$ & 0500 & $91 / 06 / 15$ & 1545 & 1.40 & 1.2 & 9.7 & 70 \\
\hline $91 / 10 / 29$ & 1000 & $91 / 10 / 31$ & 1400 & 1.02 & 1.00 & 1.8 & 58 \\
\hline $91 / 11 / 01$ & 1325 & $91 / 11 / 04$ & 0600 & .35 & .91 & .55 & 77 \\
\hline $91 / 11 / 18$ & 0700 & $91 / 11 / 20$ & 0905 & .23 & .90 & .24 & 32 \\
\hline $91 / 11 / 29$ & 1805 & $91 / 12 / 02$ & 1610 & .78 & 10 & 64 & 590 \\
\hline $91 / 12 / 12$ & 0825 & $91 / 12 / 14$ & 0700 & .61 & 14 & 64 & 700 \\
\hline $92 / 03 / 29$ & 1500 & $92 / 03 / 31$ & 0940 & .28 & 3.9 & 5.9 & 120 \\
\hline $92 / 03 / 31$ & 1200 & $92 / 04 / 02$ & 1100 & .12 & 3.9 & 11 & 150 \\
\hline $92 / 04 / 10$ & 1700 & $92 / 04 / 13$ & 1535 & .43 & 12 & 75 & 440 \\
\hline $92 / 04 / 15$ & 1200 & $92 / 04 / 18$ & 0935 & 2.07 & 34 & 710 & 2,900 \\
\hline $92 / 04 / 19$ & 1355 & $92 / 04 / 20$ & 1815 & .19 & 3.4 & 11 & 110 \\
\hline $92 / 04 / 20$ & 1945 & $92 / 04 / 22$ & 0910 & .36 & 7.2 & 72 & 430 \\
\hline $92 / 07 / 13$ & 1820 & $92 / 07 / 16$ & 0500 & .71 & .48 & .24 & 13 \\
\hline $92 / 09 / 16$ & 0725 & $92 / 09 / 17$ & 0520 & 1.39 & .95 & 2.9 & 110 \\
\hline $92 / 09 / 18$ & 0240 & $92 / 09 / 20$ & 0800 & 1.48 & 13 & 97 & 950 \\
\hline $92 / 09 / 26$ & 1000 & $92 / 09 / 30$ & 0510 & 1.11 & 3.3 & 2.7 & 120 \\
\hline $92 / 11 / 01$ & 1900 & $92 / 11 / 03$ & 2300 & 1.27 & 8.1 & 40 & 550 \\
\hline $92 / 11 / 08$ & 2300 & $92 / 11 / 12$ & 0401 & .34 & 4.1 & 3.7 & 130 \\
\hline $92 / 11 / 12$ & 1200 & $92 / 11 / 14$ & 1001 & .34 & 4.7 & 6.3 & 170 \\
\hline $92 / 11 / 20$ & 0005 & $92 / 11 / 22$ & 0530 & 1.60 & 38 & 270 & 2,500 \\
\hline $92 / 12 / 15$ & 0715 & $92 / 12 / 17$ & 2216 & 1.02 & 47 & 180 & 1,900 \\
\hline $92 / 12 / 29$ & 0600 & $92 / 12 / 31$ & 2301 & $\mathrm{~s} / \mathrm{m}$ & 1.6 & .77 & 58 \\
\hline $93 / 03 / 02$ & 1140 & $93 / 03 / 18$ & 1801 & $\mathrm{~s} / \mathrm{m}$ & 29 & 30 & 1,600 \\
\hline $93 / 03 / 24$ & 0859 & $93 / 03 / 31$ & 1501 & $\mathrm{~s} / \mathrm{m}$ & 22 & 26 & 1,100 \\
\hline $93 / 04 / 04$ & 1130 & $93 / 04 / 07$ & 1101 & $\mathrm{~s} / \mathrm{m}$ & 9.5 & 22 & 350 \\
\hline $93 / 04 / 07$ & 1345 & $93 / 04 / 10$ & 0101 & .76 & 28 & 290 & 1,700 \\
\hline $93 / 04 / 11$ & 1459 & $93 / 04 / 14$ & 0801 & $\mathrm{~s} / \mathrm{m}$ & 7.4 & 8.0 & 230 \\
\hline $93 / 04 / 15$ & 0559 & $93 / 04 / 19$ & 0301 & 1.01 & 46 & 420 & 2,400 \\
\hline $93 / 04 / 19$ & 0900 & $93 / 04 / 23$ & 0801 & .49 & 32 & 140 & 1,300 \\
\hline $93 / 04 / 27$ & 1729 & $93 / 04 / 29$ & 1401 & .55 & 8.5 & 27 & 340 \\
\hline $93 / 05 / 30$ & 1245 & $93 / 06 / 03$ & 0531 & .92 & 4.0 & 2.5 & 110 \\
\hline
\end{tabular}


Appendix. Storm-load data for rural watershed-management evaluation monitoring sites, Wisconsin, water years ${ }^{1}$ 1985-98-Continued

[yr, year; mo, month; d, day; h, hour; in., inches; $\mathrm{Mft}^{3}$, million cubic feet; $1 \mathrm{~b}$, pounds; s/m, snowmelt; --, no data]

\begin{tabular}{|c|c|c|c|c|c|c|c|}
\hline \multicolumn{2}{|c|}{ Start of storm } & \multicolumn{2}{|c|}{ End of storm } & \multirow[b]{2}{*}{$\begin{array}{l}\text { Precipltation } \\
\text { (in.) }\end{array}$} & \multirow[b]{2}{*}{$\begin{array}{c}\text { Streamflow } \\
\text { volume } \\
\left(\mathrm{Mft}^{3}\right)\end{array}$} & \multicolumn{2}{|c|}{ Loads } \\
\hline $\begin{array}{c}\text { Date } \\
(\mathrm{yr} / \mathrm{mo} / \mathrm{d})\end{array}$ & $\begin{array}{l}\text { Time } \\
(24 \mathrm{~h})\end{array}$ & $\begin{array}{c}\text { Date } \\
\text { (yr/mo/d) }\end{array}$ & $\begin{array}{l}\text { Time } \\
(24 \mathrm{~h})\end{array}$ & & & $\begin{array}{l}\text { Suspended- } \\
\text { solids load } \\
\text { (tons) }\end{array}$ & $\begin{array}{c}\text { Totai- } \\
\text { phosphorus } \\
\text { load } \\
\text { (Ib) }\end{array}$ \\
\hline \multicolumn{8}{|c|}{ Bower Creek-Continued } \\
\hline $93 / 06 / 08$ & 0300 & $93 / 06 / 11$ & 1201 & 2.51 & 38 & 1,100 & 3,600 \\
\hline $93 / 06 / 14$ & 0225 & $93 / 06 / 16$ & 0021 & .96 & 6.9 & 110 & 480 \\
\hline $93 / 08 / 05$ & 2300 & $93 / 08 / 08$ & 1700 & 1.18 & 1.6 & 5.1 & - \\
\hline $93 / 10 / 15$ & 1730 & $93 / 10 / 19$ & 0300 & -- & 1.8 & 1.4 & 19 \\
\hline $93 / 10 / 20$ & 2200 & $93 / 10 / 23$ & 2200 & -- & 2.2 & 1.5 & 78 \\
\hline $93 / 11 / 12$ & 2200 & $93 / 11 / 18$ & 0600 & -- & 3.2 & 1.2 & 68 \\
\hline $93 / 11 / 26$ & 0700 & $93 / 11 / 29$ & 0900 & -- & 2.9 & 3.6 & 89 \\
\hline $94 / 02 / 19$ & 0700 & $94 / 02 / 25$ & 0300 & -- & 78 & 46 & 930 \\
\hline $94 / 03 / 04$ & 1200 & $94 / 03 / 09$ & 2200 & - & 36 & 48 & 770 \\
\hline $94 / 04 / 12$ & 1500 & $94 / 04 / 14$ & 1000 & -- & 3.3 & 7.3 & 65 \\
\hline $94 / 04 / 15$ & 0245 & $94 / 04 / 17$ & 0900 & -- & 5.9 & 37 & 230 \\
\hline $94 / 04 / 24$ & 2000 & $94 / 04 / 27$ & 0345 & - & 45 & 2,200 & 6.000 \\
\hline $94 / 07 / 04$ & 0100 & $94 / 07 / 09$ & 2100 & -- & 3.2 & 6.6 & 100 \\
\hline $96 / 04 / 18$ & 2200 & $96 / 04 / 19$ & 2355 & .29 & 39 & 4 & 93 \\
\hline $96 / 04 / 20$ & 0900 & $96 / 04 / 21$ & 1700 & .55 & 110 & 71 & 530 \\
\hline $96 / 06 / 07$ & 0300 & $96 / 06 / 08$ & 2300 & 1.51 & 270 & 220 & 1,500 \\
\hline $96 / 06 / 10$ & 1000 & $96 / 06 / 12$ & 2355 & .20 & 52 & 5.3 & 160 \\
\hline $96 / 06 / 17$ & 0200 & $96 / 06 / 20$ & 0500 & 3.16 & 730 & 1200 & 5,000 \\
\hline $96 / 07 / 29$ & 1700 & $96 / 07 / 30$ & 2300 & .30 & 28 & 28 & 240 \\
\hline $97 / 01 / 04$ & 1200 & $97 / 01 / 06$ & 2355 & .84 & 21 & .2 & 15 \\
\hline $97 / 01 / 22$ & 0300 & $97 / 01 / 24$ & 2355 & $\mathrm{~s} / \mathrm{m}$ & 78 & 1.3 & 84 \\
\hline $97 / 02 / 18$ & 1100 & $97 / 02 / 20$ & 2355 & $\mathrm{~s} / \mathrm{m}$ & 480 & 11 & 480 \\
\hline $97 / 03 / 21$ & 1300 & $97 / 03 / 24$ & 2355 & $\mathrm{~s} / \mathrm{m}$ & 260 & 9.8 & 510 \\
\hline $97 / 03 / 26$ & 0900 & $97 / 03 / 29$ & 2355 & $\mathrm{~s} / \mathrm{m}$ & 760 & 180 & 1,500 \\
\hline $97 / 04 / 30$ & 2200 & $97 / 05 / 02$ & 1700 & 1.83 & 68 & 30 & 270 \\
\hline $97 / 06 / 07$ & 0900 & $97 / 06 / 09$ & 0400 & 1.06 & 6.6 & .17 & 8.8 \\
\hline $97 / 06 / 12$ & 0400 & $97 / 06 / 13$ & 0500 & .46 & 4.2 & .16 & 6.7 \\
\hline $97 / 06 / 20$ & 0300 & $97 / 06 / 21$ & 0400 & 1.28 & 73 & 230 & 560 \\
\hline $97 / 06 / 21$ & 0900 & $97 / 06 / 22$ & 2000 & .79 & 99 & 63 & 440 \\
\hline $97 / 06 / 23$ & 0500 & $97 / 06 / 23$ & 2200 & .19 & 12 & .65 & 26 \\
\hline \multicolumn{8}{|c|}{ Otter Creek } \\
\hline $90 / 09 / 06$ & 1940 & $90 / 09 / 08$ & 1845 & 1.53 & 1.5 & 7.1 & 63 \\
\hline $90 / 09 / 14$ & 0540 & $90 / 09 / 18$ & 2335 & 1.67 & 6.5 & 26 & 190 \\
\hline $90 / 11 / 05$ & 0610 & $90 / 11 / 06$ & 1030 & .79 & 1.2 & 1.2 & 20 \\
\hline $91 / 02 / 03$ & 0300 & $91 / 02 / 08$ & 1400 & $\mathrm{~s} / \mathrm{m}$ & 10 & 11 & 180 \\
\hline $91 / 03 / 01$ & 1100 & $91 / 03 / 04$ & 1600 & $\mathrm{~s} / \mathrm{m}$ & 5.3 & 27 & - \\
\hline
\end{tabular}


Appendix. Storm-load data for rural watershed-management evaluation monitoring sites, Wisconsin, water years ${ }^{1}$ 1985-98-Continued

[yr, year; mo, month; d. day; h, hour; in.. inches: Mft ${ }^{3}$. million cubic feet; lb. pounds; s/m, snowmelt; --, no data]

\begin{tabular}{|c|c|c|c|c|c|c|c|}
\hline \multicolumn{2}{|c|}{ Start of storm } & \multicolumn{2}{|c|}{ End of storm } & \multirow[b]{2}{*}{$\begin{array}{l}\text { Precipitation } \\
\text { (in.) }\end{array}$} & \multirow[b]{2}{*}{$\begin{array}{l}\text { Streamflow } \\
\text { volume } \\
\left(\mathrm{Mft}^{3}\right)\end{array}$} & \multicolumn{2}{|c|}{ Loads } \\
\hline $\begin{array}{c}\text { Date } \\
(\mathrm{yr} / \mathrm{mo} / \mathrm{d})\end{array}$ & $\begin{array}{l}\text { Time } \\
(24 \mathrm{~h})\end{array}$ & $\begin{array}{c}\text { Date } \\
(\mathrm{yr} / \mathrm{mo} / \mathrm{d})\end{array}$ & $\begin{array}{l}\text { Time } \\
(24 \mathrm{~h})\end{array}$ & & & $\begin{array}{l}\text { Suspended- } \\
\text { soiids load } \\
\text { (tons) }\end{array}$ & $\begin{array}{c}\text { Total- } \\
\text { phosphorus } \\
\text { loed } \\
\text { (b) }\end{array}$ \\
\hline \multicolumn{8}{|c|}{ Otter Creek-Continued } \\
\hline $91 / 06 / 14$ & 1735 & $91 / 06 / 18$ & 0300 & 2.24 & 5.2 & 35 & 230 \\
\hline $91 / 10 / 24$ & 1200 & $91 / 10 / 26$ & 1245 & 1.85 & 2.0 & 8.3 & 57 \\
\hline $91 / 10 / 26$ & 1245 & $91 / 10 / 27$ & 2300 & .46 & 1.4 & 1.6 & 23 \\
\hline $91 / 10 / 29$ & 0225 & $91 / 10 / 30$ & 1910 & -- & 2.6 & 11 & 83 \\
\hline $91 / 11 / 01$ & 1200 & $91 / 11 / 03$ & 0005 & .53 & 2.2 & 8.1 & 70 \\
\hline $91 / 11 / 14$ & 1535 & $91 / 11 / 17$ & 0155 & .46 & 2.0 & 3.0 & 24 \\
\hline $91 / 11 / 18$ & 0140 & $91 / 11 / 20$ & 1810 & .39 & 2.7 & 7.6 & 45 \\
\hline $91 / 11 / 29$ & 2015 & $91 / 12 / 02$ & 2235 & 1.38 & 6.7 & 19 & 150 \\
\hline $92 / 02 / 27$ & 1200 & $92 / 03 / 01$ & 0900 & $\mathrm{~s} / \mathrm{m}$ & 4.1 & 12 & 110 \\
\hline $92 / 03 / 01$ & 0900 & $92 / 03 / 03$ & 0900 & $\mathrm{~s} / \mathrm{m}$ & 4.1 & 14 & 130 \\
\hline $92 / 03 / 05$ & 2100 & $92 / 03 / 08$ & 1100 & .37 & 5.8 & 15 & 100 \\
\hline $92 / 03 / 09$ & 0335 & $92 / 03 / 10$ & 1930 & .55 & 4.8 & 24 & 98 \\
\hline $92 / 03 / 24$ & 1200 & $92 / 03 / 28$ & 0700 & $\mathrm{~s} / \mathrm{m}$ & 6.0 & 8.3 & 82 \\
\hline $92 / 04 / 10$ & 1800 & $92 / 04 / 13$ & 0500 & .81 & 4.1 & 19 & 82 \\
\hline $92 / 04 / 16$ & 0500 & $92 / 04 / 18$ & 0540 & .80 & 4.5 & 25 & 110 \\
\hline $92 / 09 / 14$ & 1230 & $92 / 09 / 15$ & 0600 & 1.01 & .24 & .27 & 2.8 \\
\hline $92 / 09 / 16$ & 0950 & $92 / 09 / 17$ & 0640 & 1.00 & .41 & 1.1 & 13 \\
\hline $92 / 09 / 18$ & 0440 & $92 / 09 / 19$ & 0735 & 1.09 & .82 & 3.1 & 25 \\
\hline $92 / 09 / 26$ & 2110 & $92 / 09 / 28$ & 1700 & .74 & .63 & .52 & 5.2 \\
\hline $92 / 11 / 01$ & 1600 & $92 / 11 / 03$ & 1600 & 1.55 & 2.4 & 6.5 & 57 \\
\hline $92 / 11 / 12$ & 0800 & $92 / 11 / 13$ & 1901 & .39 & .92 & .62 & 9.3 \\
\hline $92 / 11 / 19$ & 2300 & $92 / 11 / 22$ & 1701 & .84 & 4.2 & 16 & 120 \\
\hline $92 / 11 / 25$ & 1900 & $92 / 11 / 27$ & 1901 & .35 & 2.7 & 3.0 & 53 \\
\hline $92 / 12 / 15$ & 0520 & $92 / 12 / 17$ & 1301 & .97 & 7.6 & 32 & 220 \\
\hline $92 / 12 / 29$ & 0744 & $92 / 12 / 30$ & 0731 & .30 & .83 & .44 & 7.8 \\
\hline $93 / 03 / 24$ & 1050 & $93 / 04 / 01$ & 1201 & $\mathrm{~s} / \mathrm{m}$ & 29 & 39 & 450 \\
\hline $93 / 04 / 03$ & 1400 & $93 / 04 / 06$ & 0900 & $\mathrm{~s} / \mathrm{m}$ & 5.7 & 4.8 & 58 \\
\hline $93 / 04 / 08$ & 0035 & $93 / 04 / 09$ & 1833 & 1.10 & 12 & 45 & 270 \\
\hline $93 / 04 / 11$ & 1100 & $93 / 04 / 13$ & 1001 & .45 & 6.4 & 5.3 & 69 \\
\hline $93 / 04 / 15$ & 0335 & $93 / 04 / 17$ & 0713 & 1.43 & 18 & 74 & 420 \\
\hline $93 / 04 / 19$ & 1505 & $93 / 04 / 21$ & 2152 & 1.50 & 20 & 67 & 440 \\
\hline 93/06/07 & 1230 & $93 / 06 / 09$ & 2045 & 2.39 & 14 & 140 & 510 \\
\hline $93 / 07 / 05$ & 1700 & $93 / 07 / 07$ & 2100 & 2.04 & 12 & 160 & 580 \\
\hline 93/07/09 & 0300 & $93 / 07 / 10$ & 2200 & 1.42 & 8.0 & 120 & 410 \\
\hline $93 / 09 / 13$ & 1045 & $93 / 09 / 16$ & 0700 & 2.34 & 2.3 & 3.7 & 37 \\
\hline $93 / 09 / 20$ & 1435 & $93 / 09 / 22$ & 0900 & 1.49 & 2.6 & 12 & 78 \\
\hline $93 / 12 / 24$ & 2100 & $94 / 01 / 04$ & 0500 & -- & 18 & .0034 & .039 \\
\hline
\end{tabular}


Appendix. Storm-load data for rural watershed-management evaluation monitoring sites, Wisconsin, water years ${ }^{1}$ 1985-98-Continued

[yr, year; mo, month; d, day; h, hour; in., inches; Mft $^{3}$, million cubic feet; lb, pounds; s/m, snowmelt; --, no data]

\begin{tabular}{|c|c|c|c|c|c|c|c|}
\hline \multicolumn{2}{|c|}{ Start of storm } & \multicolumn{2}{|c|}{ End of storm } & \multirow[b]{2}{*}{$\begin{array}{l}\text { Precipitation } \\
\text { (in.) }\end{array}$} & \multirow[b]{2}{*}{$\begin{array}{l}\text { Streamflow } \\
\text { voiume } \\
\left(\mathrm{Mft}^{3}\right)\end{array}$} & \multicolumn{2}{|c|}{ Loads } \\
\hline $\begin{array}{c}\text { Date } \\
(y r / m o / d)\end{array}$ & $\begin{array}{l}\text { Time } \\
(24 h)\end{array}$ & $\begin{array}{c}\text { Date } \\
(y r / m o / d)\end{array}$ & $\begin{array}{l}\text { Time } \\
(24 \mathrm{~h})\end{array}$ & & & $\begin{array}{l}\text { Suspended- } \\
\text { solids ioad } \\
\text { (tons) }\end{array}$ & $\begin{array}{c}\text { Totai- } \\
\text { phosphorus } \\
\text { load } \\
\text { (lb) }\end{array}$ \\
\hline \multicolumn{8}{|c|}{ Otter Creek-Continued } \\
\hline $94 / 03 / 20$ & 1200 & $94 / 03 / 25$ & 0800 & -- & 10 & 9 & 85 \\
\hline $94 / 04 / 24$ & 2200 & $94 / 04 / 27$ & 0800 & - & 4.1 & 9.9 & 70 \\
\hline $94 / 05 / 25$ & 1900 & $94 / 05 / 27$ & 2200 & -- & 2.2 & 34 & 130 \\
\hline $94 / 08 / 01$ & 0200 & $94 / 08 / 02$ & 2100 & -- & .82 & .52 & 8.2 \\
\hline $95 / 03 / 11$ & 1100 & $95 / 03 / 13$ & 1100 & $\mathrm{~s} / \mathrm{m}$ & 64 & 33 & 220 \\
\hline $95 / 03 / 12$ & 0005 & $96 / 03 / 17$ & 1100 & $\mathrm{~s} / \mathrm{m}$ & 68 & 16 & 110 \\
\hline $95 / 04 / 11$ & 1400 & $95 / 04 / 13$ & 1800 & .67 & 29 & 2.7 & 31 \\
\hline $95 / 04 / 18$ & 0700 & $95 / 04 / 20$ & 0830 & 1.03 & 41 & 9.6 & 73 \\
\hline $95 / 10 / 31$ & 2100 & $95 / 11 / 03$ & 0200 & 1.51 & 31 & 17 & 96 \\
\hline $96 / 01 / 18$ & 0005 & $96 / 01 / 22$ & 2345 & .43 & 89 & 6.4 & 140 \\
\hline $96 / 02 / 08$ & 0005 & $96 / 02 / 13$ & 2345 & $\mathrm{~s} / \mathrm{m}$ & 96 & 5.3 & 190 \\
\hline $96 / 02 / 23$ & 0005 & $96 / 03 / 01$ & 2345 & $\mathrm{~s} / \mathrm{m}$ & 120 & 19 & 220 \\
\hline $96 / 04 / 18$ & 2000 & $96 / 04 / 19$ & 1800 & .46 & 20 & 4 & 33 \\
\hline $96 / 04 / 29$ & 1600 & $96 / 05 / 02$ & 1000 & .63 & 38 & 1.2 & 25 \\
\hline $96 / 05 / 10$ & 0005 & $96 / 05 / 11$ & 2300 & .64 & 28 & 2.9 & 30 \\
\hline $96 / 06 / 07$ & 0200 & $96 / 06 / 09$ & 0100 & 1.12 & 67 & 20 & 130 \\
\hline $96 / 06 / 16$ & 2300 & $96 / 06 / 19$ & 1900 & 3.03 & 220 & 45 & 450 \\
\hline $97 / 02 / 18$ & 0005 & $97 / 02 / 20$ & 2355 & $\mathrm{~s} / \mathrm{m}$ & 170 & 14 & 180 \\
\hline $97 / 03 / 10$ & 1500 & $97 / 03 / 11$ & 0700 & $\mathrm{~s} / \mathrm{m}$ & 18 & 3 & 32 \\
\hline $97 / 03 / 11$ & 1000 & $97 / 03 / 12$ & 0700 & $\mathrm{~s} / \mathrm{m}$ & 22 & 3.3 & 37 \\
\hline $97 / 03 / 20$ & 0900 & $97 / 03 / 21$ & 0400 & $\mathrm{~s} / \mathrm{m}$ & 30 & 7.3 & 59 \\
\hline $97 / 03 / 21$ & 0900 & $97 / 03 / 22$ & 0900 & $\mathrm{~s} / \mathrm{m}$ & 47 & 9.9 & 86 \\
\hline $97 / 04 / 30$ & 1600 & $97 / 05 / 02$ & 0200 & 1.21 & 18 & 1.7 & 24 \\
\hline $97 / 06 / 15$ & 2300 & $97 / 06 / 16$ & 2000 & .87 & 3.5 & .11 & 3.3 \\
\hline $97 / 06 / 20$ & 0400 & $97 / 06 / 23$ & 1800 & 3.52 & 170 & 80 & 530 \\
\hline $97 / 06 / 20$ & 0400 & $97 / 06 / 20$ & 2300 & .84 & 4.7 & .54 & 7.2 \\
\hline $97 / 06 / 20$ & 2300 & $97 / 06 / 23$ & 1800 & 2.68 & 170 & 79 & 530 \\
\hline \multicolumn{8}{|c|}{ Kuenster Creek } \\
\hline $92 / 11 / 01$ & 1900 & $92 / 11 / 04$ & 0100 & 1.38 & 1.0 & 1.8 & 36 \\
\hline $92 / 11 / 19$ & 1600 & $92 / 11 / 22$ & 0100 & 2.73 & 2.4 & 19 & 300 \\
\hline $92 / 12 / 15$ & 0200 & $92 / 12 / 17$ & 0400 & $\mathrm{~s} / \mathrm{m}$ & 1.7 & 8.2 & 220 \\
\hline $93 / 03 / 05$ & 1100 & $93 / 03 / 06$ & 0400 & $\mathrm{~s} / \mathrm{m}$ & 1.7 & 85 & 440 \\
\hline 93/03/07 & 1400 & $93 / 03 / 08$ & 0700 & $\mathrm{~s} / \mathrm{m}$ & 4.2 & 2.70 & 1,200 \\
\hline $93 / 03 / 08$ & 1400 & $93 / 03 / 09$ & 0800 & $\mathrm{~s} / \mathrm{m}$ & 3.4 & 83 & 560 \\
\hline $93 / 03 / 15$ & 2300 & $93 / 03 / 17$ & 0900 & $\mathrm{~s} / \mathrm{m}$ & 6.5 & 290 & 920 \\
\hline $93 / 03 / 25$ & 1200 & $93 / 03 / 26$ & 0900 & $\mathrm{~s} / \mathrm{m}$ & 9.7 & 1,100 & 3,600 \\
\hline
\end{tabular}


Appendix. Storm-load data for rural watershed-management evaluation monitoring sites, Wisconsin, water years ${ }^{1}$ 1985-98-Continued

[yr, year; mo, month; d, day; h, hour; in., inches; $\mathrm{Mft}^{3}$, million cubic feet; lb, pounds; s/m, snowmelt; --, no data]

\begin{tabular}{|c|c|c|c|c|c|c|c|}
\hline \multicolumn{2}{|c|}{ Start of storm } & \multicolumn{2}{|c|}{ End of storm } & \multirow[b]{2}{*}{$\begin{array}{l}\text { Preclpitation } \\
\text { (In.) }\end{array}$} & \multirow[b]{2}{*}{$\begin{array}{c}\text { Streamflow } \\
\text { volume } \\
\left(\mathrm{Mft}^{3}\right)\end{array}$} & \multicolumn{2}{|c|}{ Loads } \\
\hline $\begin{array}{c}\text { Date } \\
(\mathrm{yr} / \mathrm{mo} / \mathrm{d})\end{array}$ & $\begin{array}{l}\text { Time } \\
(24 \mathrm{~h})\end{array}$ & $\begin{array}{c}\text { Date } \\
\text { (yr/mo/d) }\end{array}$ & $\begin{array}{l}\text { Time } \\
(24 h)\end{array}$ & & & $\begin{array}{l}\text { Suspended- } \\
\text { sollds load } \\
\text { (tons) }\end{array}$ & $\begin{array}{c}\text { Total- } \\
\text { phosphorus } \\
\text { load } \\
\text { (lb) }\end{array}$ \\
\hline \multicolumn{8}{|c|}{ Kuenster Creek-Continued } \\
\hline $93 / 03 / 26$ & 1200 & $93 / 03 / 27$ & 0700 & $\mathrm{~s} / \mathrm{m}$ & 7.8 & 430 & 1,400 \\
\hline $93 / 03 / 27$ & 1200 & $93 / 03 / 28$ & 0500 & $\mathrm{~s} / \mathrm{m}$ & 6.6 & 210 & 1,190 \\
\hline $93 / 03 / 28$ & 1300 & $93 / 03 / 29$ & 0600 & $\mathrm{~s} / \mathrm{m}$ & 4.1 & 91 & 540 \\
\hline $93 / 03 / 30$ & 1200 & $93 / 03 / 31$ & 1900 & 1.78 & 14 & 3,000 & 6,700 \\
\hline $93 / 05 / 02$ & 1900 & $93 / 05 / 03$ & 1000 & 1.63 & 3.8 & 340 & 1,400 \\
\hline $93 / 06 / 17$ & 1800 & $93 / 06 / 18$ & 2000 & .72 & 3.4 & 100 & 730 \\
\hline $93 / 06 / 28$ & 1600 & $93 / 06 / 29$ & 0600 & - & 1.4 & 20 & 80 \\
\hline $93 / 06 / 29$ & 2300 & $93 / 06 / 30$ & 2200 & 1.42 & 5.8 & 470 & 1,600 \\
\hline $93 / 07 / 17$ & 1000 & $93 / 07 / 17$ & 1900 & 1.07 & 2.2 & 170 & 470 \\
\hline $93 / 08 / 14$ & 1715 & $93 / 08 / 16$ & 0500 & 1.00 & 4.4 & 120 & 455 \\
\hline $93 / 08 / 18$ & 1100 & $93 / 08 / 19$ & 1100 & .88 & 2.4 & 36 & 190 \\
\hline $94 / 03 / 04$ & 1200 & $94 / 03 / 05$ & 0800 & -- & 6 & 790 & 2,000 \\
\hline $94 / 03 / 05$ & 1200 & $94 / 03 / 06$ & 1100 & - & 3 & 85 & 330 \\
\hline $94 / 06 / 20$ & 0200 & $94 / 06 / 20$ & 1300 & - & .47 & 6.6 & 49 \\
\hline $94 / 06 / 23$ & 0600 & $94 / 06 / 24$ & 2200 & - & 4.9 & 130 & 490 \\
\hline $94 / 07 / 04$ & 0800 & $94 / 07 / 05$ & 1900 & - & 2.4 & 95 & 390 \\
\hline $94 / 07 / 14$ & 0100 & $94 / 07 / 15$ & 0300 & - & 2.9 & 190 & 140 \\
\hline $94 / 07 / 20$ & 0000 & $94 / 07 / 21$ & 0200 & -- & 2.1 & 55 & 230 \\
\hline $95 / 04 / 11$ & 1800 & $95 / 04 / 13$ & 0300 & 1.53 & 19 & 16 & 130 \\
\hline $95 / 05 / 09$ & 1900 & $95 / 05 / 11$ & 0300 & 1.05 & 28 & 79 & 360 \\
\hline $95 / 07 / 27$ & 1500 & $95 / 07 / 29$ & 0300 & 1.57 & 20 & 15 & 88 \\
\hline $95 / 08 / 06$ & 1700 & $95 / 08 / 08$ & 0700 & 2.48 & 41 & 110 & 450 \\
\hline $95 / 11 / 01$ & 0700 & $95 / 11 / 03$ & 1100 & 2.12 & 27 & 39 & 200 \\
\hline $96 / 01 / 17$ & 1600 & $96 / 01 / 18$ & 2400 & .50 & 26 & 65 & 390 \\
\hline $96 / 02 / 07$ & 0800 & $96 / 02 / 15$ & 0900 & $\mathrm{~s} / \mathrm{m}$ & 130 & 38 & 1,300 \\
\hline $96 / 02 / 19$ & 0100 & $96 / 02 / 26$ & 2000 & $\mathrm{~s} / \mathrm{m}$ & 62 & 36 & 400 \\
\hline $96 / 05 / 09$ & 0200 & $96 / 05 / 11$ & 0500 & 1.65 & 18 & 55 & 410 \\
\hline $96 / 05 / 28$ & 0500 & $96 / 05 / 29$ & 2100 & 1.07 & 18 & 11 & 110 \\
\hline $96 / 06 / 01$ & 1800 & $96 / 06 / 02$ & 2000 & .89 & 9.9 & 4.7 & 22 \\
\hline $96 / 06 / 06$ & 0400 & $96 / 06 / 08$ & 0800 & .82 & 34 & 61 & 410 \\
\hline $96 / 06 / 16$ & 1600 & $96 / 06 / 18$ & 1600 & 1.62 & 25 & 36 & 270 \\
\hline $96 / 06 / 29$ & 2100 & $96 / 07 / 01$ & 0500 & 1.22 & 10 & 4.9 & 34 \\
\hline \multicolumn{8}{|c|}{ Rattlesnake Creek } \\
\hline $90 / 01 / 16$ & 1700 & $90 / 01 / 18$ & 0800 & $\mathrm{~s} / \mathrm{m}$ & 9.4 & 150 & 1,600 \\
\hline $90 / 03 / 08$ & 0600 & $90 / 03 / 08$ & 1200 & $\mathrm{~s} / \mathrm{m}$ & 16 & 1,300 & 3,600 \\
\hline $90 / 03 / 11$ & 0500 & $90 / 03 / 12$ & 0200 & $\mathrm{~s} / \mathrm{m}$ & 4.1 & 57 & 480 \\
\hline
\end{tabular}


Appendix. Storm-load data for rural watershed-management evaluation monitoring sites, Wisconsin, water years ${ }^{1}$ 1985-98-Continued

[yr, year; mo, month; d, day; h, hour; in., inches; Mft ${ }^{3}$, million cubic feet; lb, pounds; s/m, snowmelt; --, no data]

\begin{tabular}{|c|c|c|c|c|c|c|c|}
\hline \multicolumn{2}{|c|}{ Start of storm } & \multicolumn{2}{|c|}{ End of storm } & \multirow[b]{2}{*}{$\begin{array}{l}\text { Precipitation } \\
\text { (in.) }\end{array}$} & \multirow[b]{2}{*}{$\begin{array}{l}\text { Streamflow } \\
\text { volume } \\
\left(\mathrm{Mft}^{3}\right)\end{array}$} & \multicolumn{2}{|c|}{ Loads } \\
\hline $\begin{array}{c}\text { Date } \\
\text { (yr/mo/d) }\end{array}$ & $\begin{array}{c}\text { Time } \\
(24 \mathrm{~h})\end{array}$ & $\begin{array}{c}\text { Date } \\
\text { (yr/mo/d) }\end{array}$ & $\begin{array}{c}\text { Time } \\
(24 \mathrm{~h})\end{array}$ & & & $\begin{array}{l}\text { Suspended- } \\
\text { solids ioad } \\
\text { (tons) }\end{array}$ & $\begin{array}{c}\text { Totai- } \\
\text { phosphorus } \\
\text { ioad } \\
\text { (lb) }\end{array}$ \\
\hline \multicolumn{8}{|c|}{ Rattlesnake Creek-Continued } \\
\hline $90 / 05 / 09$ & 0115 & $90 / 05 / 10$ & 0100 & -- & 3.2 & 170 & 360 \\
\hline $90 / 05 / 19$ & 0500 & $90 / 05 / 20$ & 2100 & - & 5.8 & 83 & 530 \\
\hline $90 / 06 / 22$ & 0315 & $90 / 06 / 22$ & 1800 & $-\infty$ & 3.3 & 55 & 180 \\
\hline $90 / 08 / 24$ & 2000 & $90 / 08 / 25$ & 2300 & - & 7.9 & 230 & 1,600 \\
\hline $90 / 08 / 26$ & 0900 & $90 / 08 / 27$ & 0400 & - & 5.6 & 190 & 940 \\
\hline $91 / 04 / 12$ & 1100 & $91 / 04 / 13$ & 1900 & 1.64 & 14 & 98 & 1,000 \\
\hline $91 / 08 / 07$ & 2000 & $91 / 08 / 08$ & 2300 & 2.50 & 8.3 & 200 & 4,600 \\
\hline $91 / 11 / 01$ & 0045 & $91 / 11 / 02$ & 0330 & 1.55 & 5.9 & 59 & 650 \\
\hline $91 / 11 / 29$ & 1100 & $91 / 11 / 30$ & 1700 & .80 & 6.2 & 29 & 230 \\
\hline $92 / 02 / 03$ & 1300 & $92 / 02 / 04$ & 0900 & $\mathrm{~s} / \mathrm{m}$ & 3.7 & 69 & 290 \\
\hline $92 / 02 / 20$ & 1445 & $92 / 02 / 21$ & 0800 & $\mathrm{~s} / \mathrm{m}$ & 19 & 2,800 & 7,600 \\
\hline $92 / 02 / 22$ & 1400 & $92 / 02 / 23$ & 1635 & $\mathrm{~s} / \mathrm{m}$ & 14 & 1,600 & 4,400 \\
\hline $92 / 02 / 24$ & 1500 & $92 / 02 / 25$ & 0900 & .24 & 8.6 & 420 & 1,700 \\
\hline $92 / 04 / 20$ & 1300 & $92 / 04 / 21$ & 0900 & .91 & 4.4 & 34 & 520 \\
\hline $92 / 06 / 16$ & 1000 & $92 / 06 / 17$ & 0300 & .66 & 1.3 & .44 & 14 \\
\hline $92 / 09 / 07$ & 2230 & $92 / 09 / 08$ & 1800 & .90 & 2.3 & 4.1 & 180 \\
\hline $92 / 09 / 14$ & 1400 & $92 / 09 / 15$ & 1800 & .84 & 2.3 & 2.9 & 130 \\
\hline $92 / 11 / 01$ & 1600 & $92 / 11 / 03$ & 1000 & 1.25 & 3.7 & 3.3 & 64 \\
\hline $92 / 11 / 19$ & 2000 & $92 / 11 / 21$ & 2200 & 2.68 & 10 & 68 & 1,300 \\
\hline $92 / 12 / 15$ & 0100 & $92 / 12 / 17$ & 0400 & .91 & 7.6 & 27 & 510 \\
\hline $93 / 03 / 03$ & 0300 & $93 / 03 / 05$ & 0600 & .27 & 16 & 2,100 & 4,000 \\
\hline $93 / 03 / 05$ & 1400 & $93 / 03 / 06$ & 0800 & $\mathrm{~s} / \mathrm{m}$ & 7.7 & 330 & 1,700 \\
\hline $93 / 03 / 06$ & 1500 & $93 / 03 / 07$ & 0800 & $\mathrm{~s} / \mathrm{m}$ & 4.8 & 120 & 1,500 \\
\hline $93 / 03 / 07$ & 1400 & $93 / 03 / 08$ & 1000 & $\mathrm{~s} / \mathrm{m}$ & 19 & 610 & 4,700 \\
\hline $93 / 03 / 08$ & 1300 & $93 / 03 / 09$ & 0900 & $\mathrm{~s} / \mathrm{m}$ & 18 & 380 & 3,600 \\
\hline $93 / 03 / 16$ & 0030 & $93 / 03 / 17$ & 0600 & $\mathrm{~s} / \mathrm{m}$ & 31 & 1,400 & 4,200 \\
\hline $93 / 03 / 24$ & 1600 & $93 / 03 / 26$ & 1100 & $\mathrm{~s} / \mathrm{m}$ & 63 & 4,300 & 14,000 \\
\hline $93 / 03 / 26$ & 1101 & $93 / 03 / 27$ & 1000 & $\mathrm{~s} / \mathrm{m}$ & 31 & 420 & 3,000 \\
\hline $93 / 03 / 27$ & 1200 & $93 / 03 / 28$ & 0800 & $\mathrm{~s} / \mathrm{m}$ & 26 & 840 & 4,300 \\
\hline $93 / 03 / 28$ & 1300 & $93 / 03 / 29$ & 0900 & $\mathrm{~s} / \mathrm{m}$ & 15 & 240 & 1,700 \\
\hline $93 / 03 / 30$ & 1300 & $93 / 03 / 31$ & 2000 & 1.67 & 43 & 4,400 & 14,000 \\
\hline $93 / 05 / 02$ & 2100 & $93 / 05 / 03$ & 1500 & 1.64 & 17 & 500 & 2,600 \\
\hline $93 / 06 / 07$ & 1000 & $93 / 06 / 08$ & 1900 & 1.53 & 13 & 260 & 1,100 \\
\hline $93 / 06 / 13$ & 2100 & $93 / 06 / 14$ & 2100 & 1.01 & 5.0 & 29 & 170 \\
\hline $93 / 06 / 17$ & 1900 & $93 / 06 / 18$ & 1500 & 1.25 & 13 & 690 & 2,700 \\
\hline $93 / 06 / 28$ & 0600 & $93 / 06 / 28$ & 1500 & .71 & 4.7 & 160 & 570 \\
\hline $93 / 06 / 29$ & 2300 & $93 / 06 / 30$ & 1800 & 1.36 & 19 & 1,300 & 4,400 \\
\hline
\end{tabular}


Appendix. Storm-load data for rural watershed-management evaluation monitoring sites, Wisconsin, water years ${ }^{1}$ 1985-98-Continued

[yr, year; mo, month; d, day; h, hour; in., inches; $\mathrm{Mft}^{3}$, million cubic feet; lb, pounds; s/m, snowmelt; --, no data]

\begin{tabular}{|c|c|c|c|c|c|c|c|}
\hline \multicolumn{2}{|c|}{ Start of storm } & \multicolumn{2}{|c|}{ End of storm } & \multirow[b]{2}{*}{$\begin{array}{l}\text { Precipitation } \\
\text { (in.) }\end{array}$} & \multirow[b]{2}{*}{$\begin{array}{l}\text { Streamfiow } \\
\text { voiume } \\
\left(\mathrm{Mft}^{3}\right)\end{array}$} & \multicolumn{2}{|c|}{ Loads } \\
\hline $\begin{array}{c}\text { Date } \\
(\mathrm{yr} / \mathrm{mo} / \mathrm{d})\end{array}$ & $\begin{array}{l}\text { Time } \\
(24 \mathrm{~h})\end{array}$ & $\begin{array}{c}\text { Date } \\
\text { (yr/mo/d) }\end{array}$ & $\begin{array}{l}\text { Time } \\
(24 \mathrm{~h})\end{array}$ & & & $\begin{array}{l}\text { Suspended- } \\
\text { soifds load } \\
\text { (tons) }\end{array}$ & $\begin{array}{c}\text { Total- } \\
\text { phosphorus } \\
\text { ioad } \\
\text { (ib) }\end{array}$ \\
\hline \multicolumn{8}{|c|}{ Rattlesnake Creek-Continued } \\
\hline $93 / 07 / 05$ & 1200 & $93 / 07 / 06$ & 1500 & 1.69 & 19 & 470 & 3,000 \\
\hline $93 / 07 / 08$ & 2330 & $93 / 07 / 09$ & 2000 & 2.35 & 71 & 8,700 & 25,000 \\
\hline $93 / 07 / 10$ & 1600 & $93 / 07 / 12$ & 0400 & 2.39 & 78 & 8,500 & 24,000 \\
\hline $93 / 07 / 17$ & 0900 & $93 / 07 / 18$ & 0200 & 0.97 & 12 & 480 & 1,700 \\
\hline $93 / 08 / 14$ & 1700 & $93 / 08 / 15$ & 0545 & .97 & 6.5 & 130 & 590 \\
\hline $93 / 08 / 15$ & 0900 & $93 / 08 / 16$ & 0100 & .74 & 10 & 150 & 810 \\
\hline $93 / 08 / 18$ & 1300 & $93 / 08 / 19$ & 0600 & 1.00 & 11 & 220 & 1,200 \\
\hline $94 / 02 / 18$ & 1600 & $94 / 02 / 21$ & 0800 & -. & 160 & 4200 & 15000 \\
\hline $94 / 03 / 04$ & 1300 & $94 / 03 / 05$ & 0900 & - & 27 & 1900 & 6300 \\
\hline $94 / 03 / 05$ & 1100 & $94 / 03 / 06$ & 0900 & - & 13 & 290 & 1600 \\
\hline $94 / 06 / 20$ & 0100 & $94 / 06 / 20$ & 1900 & - & 2.7 & 20 & 83 \\
\hline $94 / 06 / 23$ & 0700 & $94 / 06 / 24$ & 2300 & -- & 16 & 520 & 2200 \\
\hline $94 / 07 / 04$ & 0700 & $94 / 07 / 05$ & 1800 & - & 7.8 & 170 & 870 \\
\hline $94 / 07 / 14$ & 0200 & $94 / 07 / 14$ & 2000 & - & 6.4 & 320 & 280 \\
\hline $94 / 07 / 20$ & 0015 & $94 / 07 / 20$ & 1700 & - & 5.5 & 140 & 730 \\
\hline
\end{tabular}

'Water year is the 12-month period, October 1 through September 30 . The water year is designated by the calendar year in which it ends. Thus, the year ending October 1, 1997, and ending September 30, 1998, is called "water year 1998." 